\title{
Two new species of the genus Oryctopterus (Orthoptera: Stenopelmatidae: Oryctopinae) from India, with some notes on biology
}

\author{
S.R. HIREMATH ${ }^{1} \&$ K.D. PRATHAPAN ${ }^{2, *}$ \\ ${ }^{1,2}$ Department of Agricultural Entomology, Kerala Agricultural University,Vellayani PO, \\ Trivandrum-695 522, Kerala, India. \\ *Corresponding author: prathapankd@gmail.com \\ ${ }^{1}$ Email: sangu3711@gmail.com \\ ${ }^{1}$ urn:1sid:zoobank.org:author:77A38404-8684-420A-892B-7FCD26A7094D \\ ${ }^{2}$ urn:Isid:zoobank.org:author:68E05D80-9F21-4632-8AEE-92F3994CBEE0
}

\begin{abstract}
The genus Oryctopterus Karny, 1937 (Orthoptera, Stenopelmatidae, Oryctopinae) is reported from India for the first time and two new species, Ot. varuna sp. nov. and Ot. yeshwanthi sp. nov. are described. Male and female external genitalia of Ot. varuna sp. nov. and female genitalia of Ot. yeshwanthi sp. nov. are figured and described. Notes on seasonality, food habits and behavior of Ot. varuna sp. nov. are provided.
\end{abstract}

Keywords. Oriental Region, male genitalia, female genitalia, diet, behavior.

Hiremath S.R. \& Prathapan K.D. 2021. Two new species of the genus Oryctopterus (Orthoptera: Stenopelmatidae: Oryctopinae) from India, with some notes on biology. European Journal of Taxonomy 748: 108-137.

https://doi.org/10.5852/ejt.2021.748.1349

\section{Introduction}

Stenopelmatidae Burmeister, 1838 (Jerusalem crickets and allies) are large, mostly wingless Orthoptera Latreille, 1793 occurring in all zoogeographic regions except Australia. The family, currently represented by 39 extant species, is divided into three subfamilies viz. Oryctopinae Kevan, 1986 (five species), Siinae Gorochov, 1988 (six species) and Stenopelmatinae Burmeister, 1838 (28 species) (Cigliano et al. 2019). Limited diversity and disjunct distribution of the family indicate its relic nature.

The family is characterized by a broad and ovoid head, pronotum anteriorly wider than posteriorly, wings absent or developed, four segmented tarsi with pulvilli not widened, first tarsomeres with two pulvilli, absence of tympanal organs, unspined forecoxae, reduced or shortened ovipositor, and basal portion of cerci with bulb-like sensilla on inner side. In general, species of Stenopelmatidae are nocturnal, subterranean, rarely encountered and poorly known. Nearctic, Neotropical and Afrotropical species are better known (Weissman 2001a, 2001b; Weissman et al. 2008; Weissman \& Bazelet 2013) compared to 
those in the Oriental Region. In India, three species are known from only the original description. No information is available on the natural history of Indian Stenopelmatidae.

The subfamily Oryctopinae, represented by five species, is divided into two genera, each placed in a monotypic tribe - Oryctopus Brunner von Wattenwyl, 1888 and Oryctopterus Karny, 1937. Oryctopus is represented by four species (Op. bolivari Brunner von Wattenwyl, 1888, Op. bouvieri Karny, 1935 and Op. prodigiosus Bolívar, 1900, all from south India; and Op. sordellii Griffini, 1914 from Sri Lanka). Oryctopterus remains monotypic, with the single species Ot. lagenipes (Karny, 1935) described from Sri Lanka. These are fairly large, chestnut brown Jerusalem crickets. Life history of the subfamily Oryctopinae, endemic to the Ceylonese subregion of the Oriental Region, is unknown and they are rarely represented in collections. Two new species of Oryctopterus are described here, extending the distributional range of the subfamily (Fig. 70) to Kerala State in south India with the first report of the genus in India.

\section{Material and methods}

Eight females of Ot. varuna sp. nov. were observed on 10 July 2007, 8 June 2016, 3 and 8 September 2019, 10 January 2020, 3 and 21 March 2020, respectively, by the authors in the Vellayani campus of the Kerala Agricultural University, seven of which were collected while one was only photographed. Eight specimens, including a male, were gathered from the insect collections submitted by the undergraduate students of the College of Agriculture, Vellayani. However, the male specimen was lost in a fire accident after it was studied and illustrated. Three specimens, including two males, were collected by the farm workers of the Instructional Farm, College of Agriculture Vellayani, following a social media campaign. A single specimen of a second new species was borrowed from the University of Agricultural Sciences, Bangalore.

\section{Dissection}

The specimens were relaxed by immersion in a mixture of equal parts of isopropyl alcohol and water, for approx. 20-25 minutes. The abdomen was then separated from the body by inserting an insect pin between the abdomen and metasternum to tear off the tissues connecting them, followed by cutting with corneal scissors. Then, the connections between the tergites and sternites of the abdomen were cut off on one side with corneal scissors. The severed abdomen was boiled in $10 \% \mathrm{KOH}$ solution for approx. 8 minutes. The cleared abdomen was washed in water and then treated with 1-2 $\mathrm{ml}$ of dilute acetic acid to neutralize excess alkali. Another round of washing in water was done to remove excess chemicals. Finally, components of the genitalia were separated completely from sternites, tergites, muscles and other miscellaneous tissues. The vagina was inflated following Yamasako (2015) with a slight modification: instead of petroleum jelly (Yamasako 2015), $\mathrm{KY} \mathrm{Gel}^{\circledR}$ was used. Two specimens of Ot. varuna sp. nov. preserved in alcohol were dissected and the ovaries as well as internal contents of the alimentary canal were examined.

\section{Photographs}

Photographs were taken using a Canon 1300 D camera with an EFs 18-55 mm kit lens for the habitus and with an EFs 55-250 $\mathrm{mm}$ telephoto lens for the head and abdominal apex. Both the lenses were coupled with a Raynox DCR-150 macro close-up lens for higher magnification and mounted on a Wemacro rail to obtain several images at different focal planes. The genitalia and contents of the alimentary canal were photographed using a Canon 1300 D camera coupled with an inverted DCR-150 Raynox macro lens mounted on a Zeiss Axiostar plus compound microscope, after removing the head of the microscope. Images were stacked using Zerene stacker ver. 1.04 and edited using Photoshop CC 2019. 
Images of the type of Oryctopterus lagenipes, made available by the Muséum national d'histoire naturelle (https://science.mnhn.fr/taxon/species/Oryctopus/lagenipes), and its original description were studied to ascertain the identity of the species described here.

Descriptive terminology follows O'Brien \& Field (2001). Types are deposited in the ICAR-National Bureau of Agricultural Insect Resources, Bangalore, India (NBAIR) and the University of Agricultural Sciences, Bangalore, India (UASB).

\section{Abbreviations}

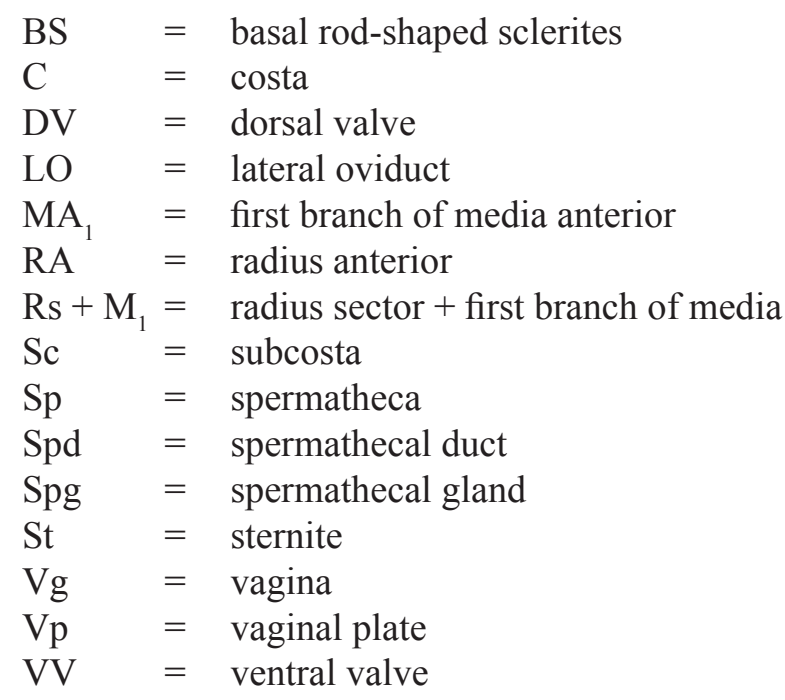

\section{Results}

Systematics

Order Orthoptera Latreille, 1793

Family Stenopelmatidae Burmeister, 1838

Subfamily Oryctopinae Kevan, 1986

Genus Oryctopterus Karny, 1937

Oryctopterus Karny, 1937: 39-41.

Oryctopterus - Gorochov 2001: 6, 20, 23-24, 26.

\section{Type species}

Oryctopus lagenipes Karny, 1935.

\section{Diagnosis}

Male alate, female apterous. Chestnut brown, smooth, shiny. Pronotal margins, legs and abdomen with bristle-like setae. Vertex broad, convex, merged with frons. Eyes small, acutely narrowed ventrally. A pair of lateral fenestra-like transparent portions present between eyes above level of antennal sockets, a similar median fenestra-like portion present a little below level of antennal sockets on vertex. Maxillary palps with four palpomeres: first small, nearly twice as long as broad; all others elongate, subequal, not distinctly thickened. Pronotum strongly convex; lateral and posterior margins narrowly bordered and explanate, anterior margin thickened, neither explanate nor narrowly bordered. Anterior margin distinctly emarginate, forming obtuse angle. Pronotum with deep anteapical transverse impression. Median 
longitudinal sulcus narrow, running between anterior and posterior margins, dividing pronotum into left and right halves. Oblique sulcus arises from anterolateral depression on either side, almost reaching near middle of posterior margin. Pronotum on either side with a weak, oblique sulcus originating from posterolateral corner, reaching oblique sulcus originating from anterolateral corner (hardly discernible in Ot. varuna sp. nov.). Prosternite broader than long, converging posteriorly, unspined. Mesothoracic basisternum longitudinally sulcate along middle, deeply emarginate posteriorly, convexly raised on either side of middle. Metathoracic basisternum wider than long. All legs with coxa, trochanter, femur unarmed. Foretibia thinner than forefemur, distinctly narrowed distally resembling a bottle, apex of tibia with two pairs of prominent spines on each side, with ventral one on either side longer than dorsal; all tarsomeres unarmed dorsally; first tarsomere longer than rest combined, claw well developed in male, absent in female. Middle tibia thick, convex dorsally, with eight spines arranged in a row around apex: two lateral, one apical, five mesal. Hind tibia with six prominent spines arranged around apex: three lateral, one apical, two mesal, mesal ones larger than rest; dorsolateral and dorsomesal margins of metatibia with row of three to six denticles, prominent in male, distinctly smaller in female. First protarsomere thin, nearly rounded, 1.4-2.4 times as long as rest combined. Cerci hardly exceeding apex of ovipositor valves, basally with bulb-like sensillae at mesal side. Supragenital plate nearly as long as broad. Subgenital plate broader than long.

\section{Remarks}

Oryctopterus can be differentiated from Oryctopus by the following characters: (1) males fully winged (Figs 1-2, 10-12) (males are apterous in Oryctopus), (2) anterior margin of pronotum emarginate forming obtuse angle (only slightly emarginate in Oryctopus), (3) anteapical transverse groove on pronotum deeply impressed (weak in Oryctopus), (4) foretibia distally narrowed, bottleshaped (foretibia distally not narrowed in Oryctopus), (5) hind tibia with 3-6 small denticles on lateral and mesal margins of dorsal surface (denticles absent on lateral and mesal margins of dorsal surface of hind tibia in Oryctopus). Shishodia et al. (2010), in their checklist of Indian Orthoptera, wrongly stated that Johns (1997) synonymized Oryctopterus with Oryctopus. Oryctopus sordellii from Sri Lanka probably belongs to Oryctopterus, as the original description states that the foretibia are apically narrowed ("Tibiae anticae apice magis angustatae") and the pronotum has a deep anteapical impression ("Pronotum, excepto sulco subito post marginum anticum transverse impress") (Griffini 1914). Moreover, in the original description, it is specified that the holotype is a male that has rudimentary wings ("rudimenta perminima elytrarum et alarum aegre conspicienda"), indicating that it could be a subadult.

Oryctopterus varuna sp. nov.

urn:lsid:zoobank.org:act:9E74ACC6-86D2-4A93-812A-5997835415D3

Figs $1-39,49-52,70$

\section{Diagnosis}

Oryctopterus varuna sp. nov. can be differentiated from Ot. lagenipes (Fig. 48) from Sri Lanka, by the following characters: (1) clypeus weakly narrowed ventrally in Ot. varuna sp. nov., more strongly narrowed ventrally in Ot. lagenipes, (2) first foretarsomere about 1.4 times as long as the rest combined in Ot. varuna sp. nov., 2.4 times as long as the rest combined in Ot. lagenipes, (3) hindwings fully developed in Ot. lagenipes (Fig. 48) (much reduced in Ot. varuna sp. nov.: Figs 1-2, 10-12). Oryctopterus varuna sp. nov. can be differentiated from Ot. yeshwanthi sp. nov. based on the structure of the mandible, pronotum and female genitalia, as mentioned under the latter species. 


\section{Etymology}

The new species is named after Varuna, the god of rains in Indian mythology. The name is a noun in apposition. This cricket was observed coming out to open areas such as campus roads following rains, hence the name. In the regional dialect, Ot. varuna sp. nov. is called 'Mannunni', meaning 'child of soil'. Also nicknamed 'Thanni-Pillai', meaning 'baby of water', alluding to its emergence following rains.

\section{Type material}

\section{Holotype}

INDIA • ${ }^{\lambda}$; Kerala, College of Agriculture, Vellayani; 18 Mar. 2021; Kumar A. leg.; "HOLOTYPE; Oryctopterus varuna sp. nov.; des. Hiremath \& Prathapan, 2021"; NBAIR.

\section{Paratypes}

INDIA • 1 Q*; same collection data as for holotype; 3 Sep. 2019; S.R. Hiremath leg.; NBAIR • 1 \%; Kerala, Vellayani; 10 Jul. 2007; K.D. Prathapan leg.; NBAIR • 1 \%; same collection data as for preceding; 23 Jul. 2015; Ashwathi leg.; NBAIR • 1 क; same collection data as for holotype; 7 Jun. 2018; Mithra Mohan leg.; NBAIR • 3 우; same collection data as for holotype; Student leg.; NBAIR • 1 \%; same collection data as for holotype; 20 Aug. 2019; Student leg.; NBAIR • 1 $^{*}$; same collection data as for holotype; 8 Sep. 2019; S.R. Hiremath leg.; NBAIR • 1 \%; same collection data as for holotype; 23 Oct. 2019; S.R. Hiremath leg.; NBAIR • 1 q; same collection data as for holotype; 3 Mar. 2020; Amritha Hari leg.; NBAIR • 1 \%; same collection data as for holotype; 21 Mar. 2020; S.R. Hiremath leg.; NBAIR • 1 \%; same collection data as for holotype; 10 Jan. 2021; Pradeep D leg.; NBAIR • 1 o; same collection data as for holotype; 21 Mar. 2021; Pradeep D leg.; NBAIR • 1 \%; same collection data as for holotype; 6 Nov. 2019; Gouripriya leg.; UASB • 1 q; same collection data as for holotype; 10 Jan. 2020; S.R. Hiremath leg.; UASB. ("Presence of mature eggs confirmed through dissection).

\section{Other material}

INDIA • $1{ }^{\lambda}$; same collection data as for holotype; 2019; Student collection leg. (lost after the specimen was studied and illustrated: Fig. 10).

\section{Description}

\section{Male (Figs 1-17)}

Coloration. General color chestnut brown; abdominal tergites, tegmina darker than head, thorax and sternites. Vertex and frons demarcated by M-shaped dark marking; a U-shaped dark stripe extends vertically over vertex (Figs 5-6), a single vertical stripe arises from each eye and a third pair of vertical stripes arise from the gena. Some of this stripes may be indistinct. Clypeus straw brown in distal half, concolorous with frons in proximal half. Labrum concolorous with frons. Tegmina chestnut brown. Abdominal tergites dark brown.

HEAD. Vertex strongly convex. Distance between eyes 1.41 times distance between antennal sockets. M-shaped dark marking demarcating vertex, frons depressed. Frons moderately convex between antennal sockets, gradually turning flat and gently depressed ventrally; without wrinkles, except few beneath eye. Eyes with mesal margin concave near antennal socket, lateral margin strongly rounded. Antenna extends well beyond apex of tegmina. Clypeus more or less as long as labrum, trapezoidal, narrowed ventrally, a little wider than long, with a vertical sulcus originating from middle of anterior margin, indistinct in proximal half. Mandibles exceed length of labrum.

Thorax. Pronotum 1.76 times wider than long, anteriorly 0.95 times wider than posteriorly (Fig. 6). Lateral margin evenly curved; anterolateral margin convex, forming somewhat obtuse angle with anterior margin. Posterior margin apparently bisinuate. Pronotal anteapical transverse impression 


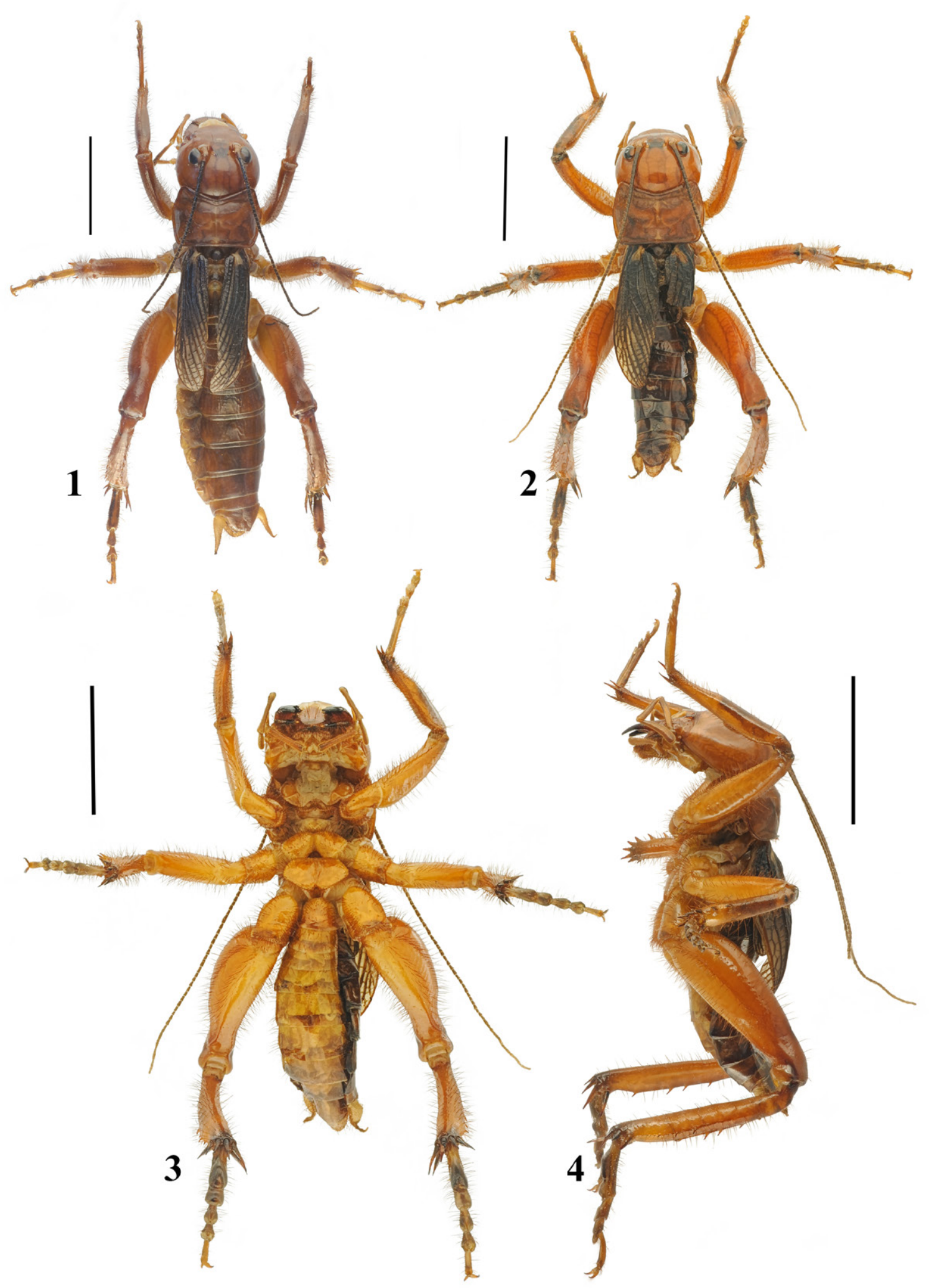

Figs 1-4. Oryctopterus varuna sp. nov., $\widehat{\jmath}$. 1. Holotype (NBAIR), dorsal habitus. 2-4. Paratypes (NBAIR). 2. Dorsal habitus. 3. Ventral habitus. 4. Lateral view. Scale bars $=10 \mathrm{~mm}$. 

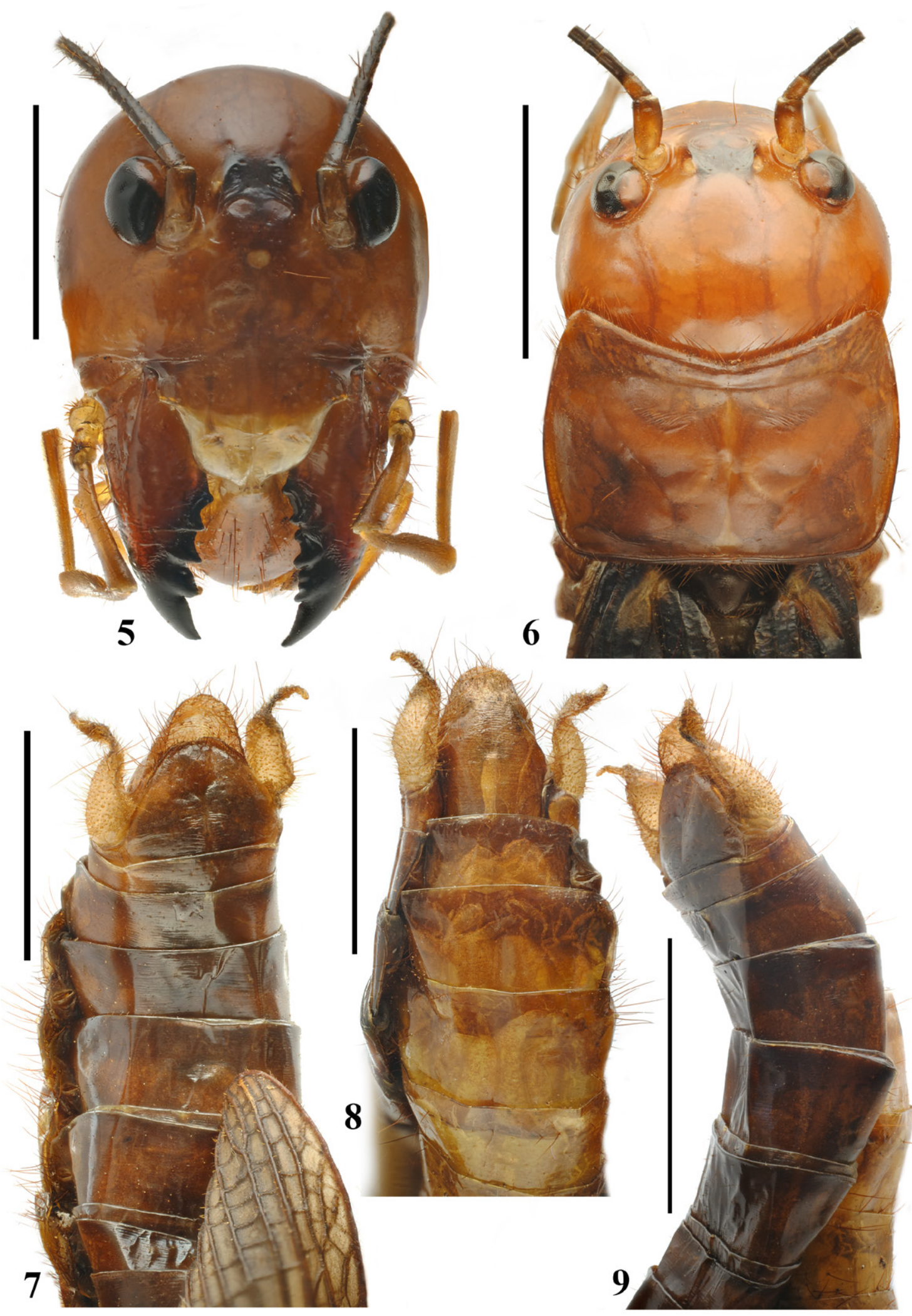

Figs 5-9. Oryctopterus varuna sp. nov. Paratype, $\widehat{\jmath}$ (NBAIR). 5. Head, frontal view. 6. Head and pronotum, dorsal view. 7-9. Apex of abdomen. 7. Dorsal view. 8. Ventral view. 9. Lateral view.Scale bars $=5 \mathrm{~mm}$. 


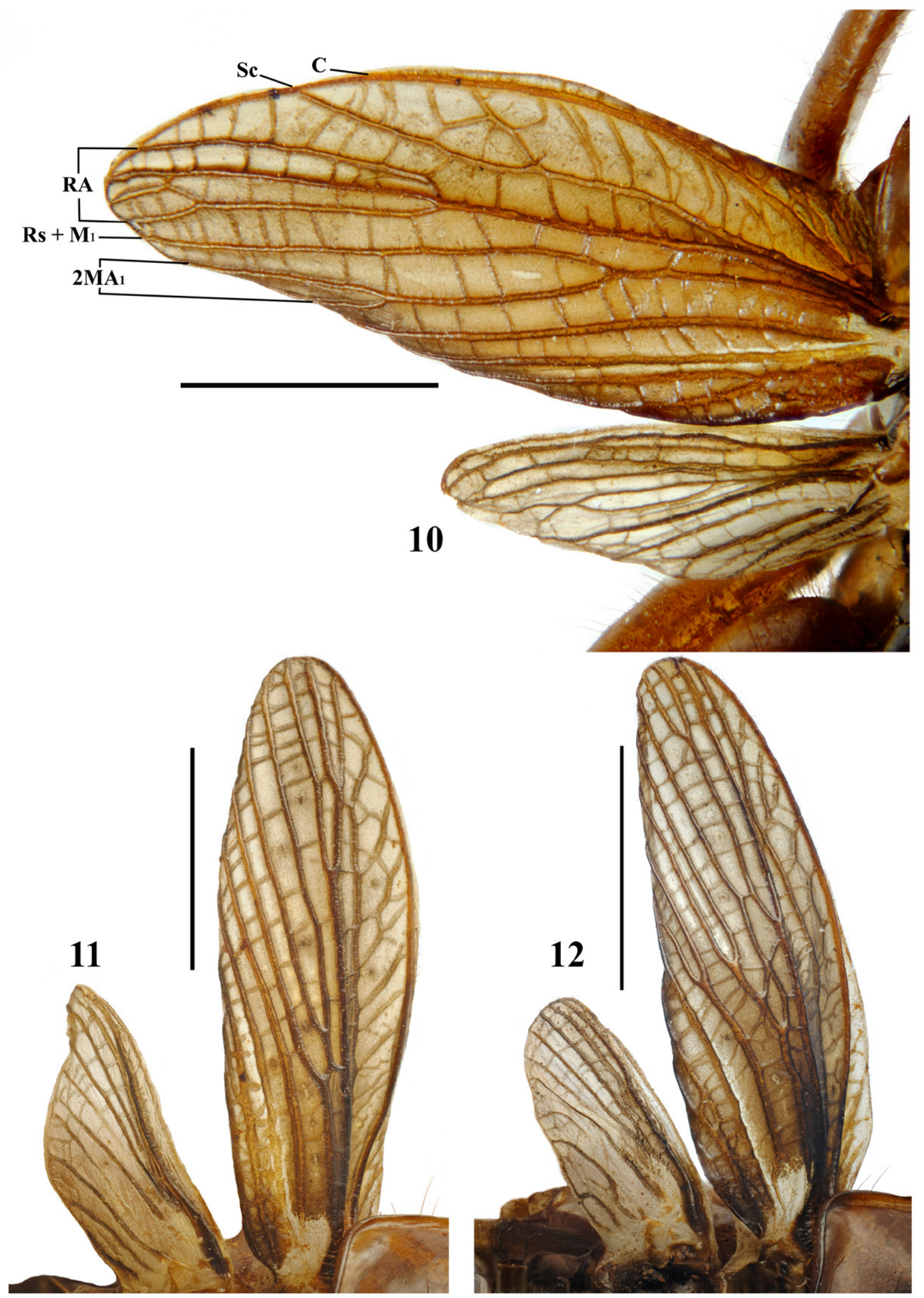

Figs 10-12. Oryctopterus varuna sp. nov., ô. 10. Lost specimen. 11. Holotype (NBAIR). 12. Paratype (NBAIR). Abbreviations: see Material and methods. Scale bars $=5 \mathrm{~mm}$. 

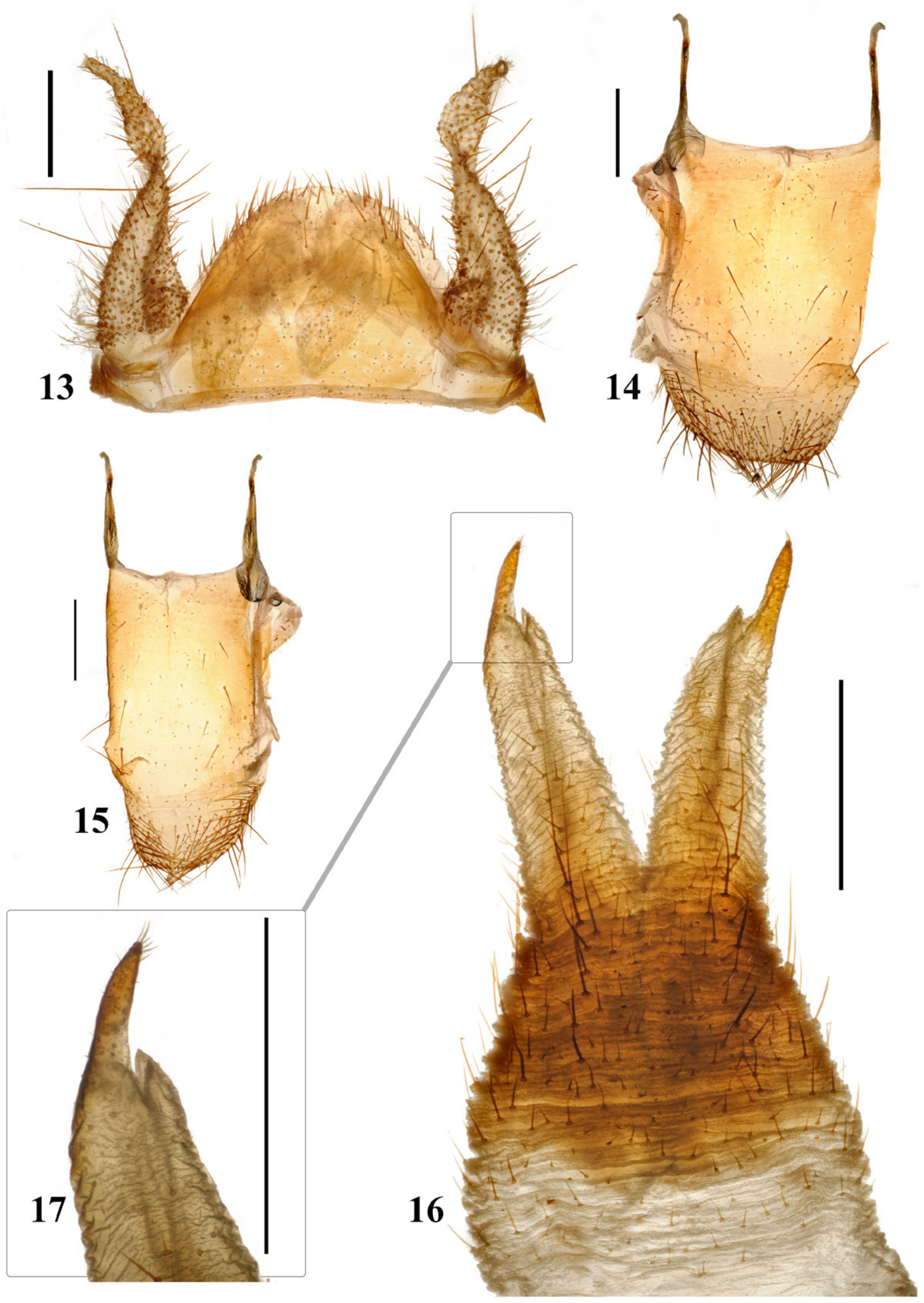

Figs 13-17. Oryctopterus varuna sp. nov. Paratype, ô (NBAIR). 13. Supragenital plate and cerci. 14. Subgenital plate, dorsal view. 15. Subgenital plate, ventral view. 16. Genital hook and associated structures, ventral view. 17. Genital hook. Scale bars $=1 \mathrm{~mm}$. 
merged with anterolateral depressions on either side. Oblique sulcus originating from postero-lateral corner of pronotum shallow. Tegmina not covering supragenital plate and 1-5 preceding tergites. Costa 3-branched, subcosta $(\mathrm{Sc})$ unbranched, reaches between apical $1 / 4$ and apex; RA 3 or 4-branched, RS $+\mathrm{M}_{1}$ unbranched or 2-branched, $2 \mathrm{MA}_{1}$ unbranched or 2-branched (Figs 10-12). Hindwings much shorter than tegmina (Figs 10-12). Prosternite wider than long, converging posteriorly, posterior margin emarginate medially, with two pairs of ventral cervical sclerites; lateral cervical sclerites acutely narrowed distally, oblique; prosternite distally with raised setose portion medially. Metathoracic basisternum with posterior margin emarginate medially.

HIND Legs. Coxa depressed ventrally. Dorsolateral and dorsomesal margins of metatibia with a row of 3-6 sharp denticles.

AвDOMEN (Figs 7-9). Supragenital plate triangular with inverted Y-shaped sulcus medially, apex rounded (Figs 1-2, 7). Subgenital plate with convex posterior margin (Figs 14-15). Subgenital plate constricted in distal third, apex rounded; with a pair of long apodemes proximally (Figs 14-15).

Genitalia (Figs 13-14). Genital hooks long, pointed, gently curved, with 6 setae on apex.

MeAsurements $(\mathrm{mm})(\mathrm{n}=3)$. Body length: $27.50-37.68$, head width: $7.55-7.89$, pronotal length: $4.42-$ 4.73, pronotal width: 8.08-8.30, forefemur: 8.94-9.11, foretibia: 9.88-10.98, foretarsi: I. 3.39-4.31, II. 0.54-1.46, III. 1.39-1.46, IV. 1.08-1.16, midfemur: 7.76-8.11, midtibia: 8.30-9.01, midtarsi: I. 1.853.08, II. 1.08-1.16, III. 1.16-1.39, IV. 1.31-2.31, hindfemur: 13.17-13.35, hindtibia: 13.47-14.81, hindtarsi: I. 2.46-4.54, II. 1.46-1.62, III. 1.54-1.85, IV. 1.54-2.70. Proportionate length of forefemur: foretibia: foretarsi: midfemur: midtibia: midtarsi: hindfemur: hindtibia: hindtarsi as follows: 1.00: 1.091.23: 0.72-0.92: 0.87-0.89: 0.92-0.98: 0.59-0.89: 1.46-1.48: 1.49-1.66: 0.77-1.19. Proportionate length of tarsomeres I-IV: foreleg - 1.00: 0.16-0.34: 0.32-0.41: 0.25-0.34; midleg - 1.00: 0.38-0.58: 0.45-0.66: 0.70-0.75; hindleg - 1.00: 0.36-0.59: 0.39-0.63: 0.59-0.63.

Female (Figs 18-39, 49-52)

Coloration. General color chestnut brown; abdomen darker than head and thorax; legs lighter than thorax. Vertex and frons demarcated by M-shaped dark marking; a U-shaped dark stripe extends vertically over vertex (Fig. 21), a single vertical stripe arise from each eye and a third pair of vertical stripes arise from the gena. The stripes may be obliterated in some specimens. Clypeus straw brown, distinctly lighter than frons. Labrum proximally concolorous with clypeus, gradually turning darker towards distal area. Thoracic sternites lighter than tergites.

Head. Vertex strongly convex. Distance between eyes 1.27-1.40 times distance between antennal sockets. Frons moderately convex between antennal sockets, gradually turning flat to depressed ventrally; minutely wrinkled in ventral half. Eyes with mesal margin concave near antennal socket, lateral margin strongly rounded. Antenna just crosses anteapical sulcus of pronotum. Clypeus a little shorter than labrum, trapezoidal, narrowed ventrally, a little over twice wider than long, with a vertical sulcus originating from middle of anterior margin, depressed on either side of vertical sulcus. Mandibles exceed length of labrum.

Thorax. Pronotum 1.67-1.79 times wider than long, anteriorly 1.12-1.26 times wider than posteriorly (Fig. 22). Lateral margin evenly curved; anterolateral margin convex, forming somewhat obtuse angle with anterior margin. Posterior margin concave medially. Pronotal anteapical transverse impression merged with anterolateral depressions on either side. Oblique sulcus originating from postero-lateral corner of pronotum not discernible. Prosternite wider than long, converging posteriorly, posterior margin emarginate medially, with two pairs of ventral cervical sclerites; lateral cervical sclerites 


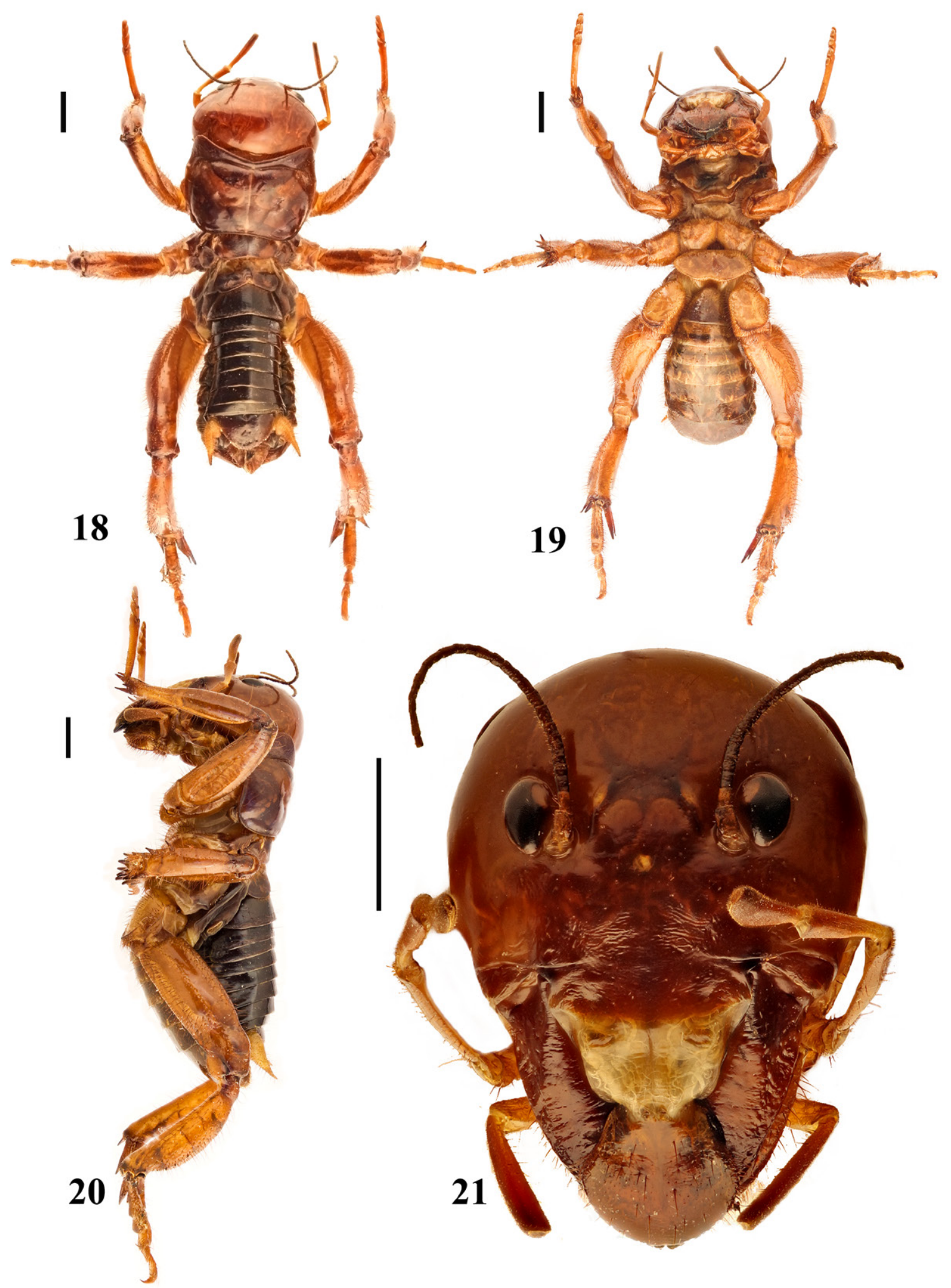

Figs 18-21. Oryctopterus varuna sp. nov. Paratype, $q$ (NBAIR). 18. Dorsal habitus. 19. Ventral habitus. 20. Lateral habitus. 20. Head, frontal view. Scale bars $=5 \mathrm{~mm}$. 

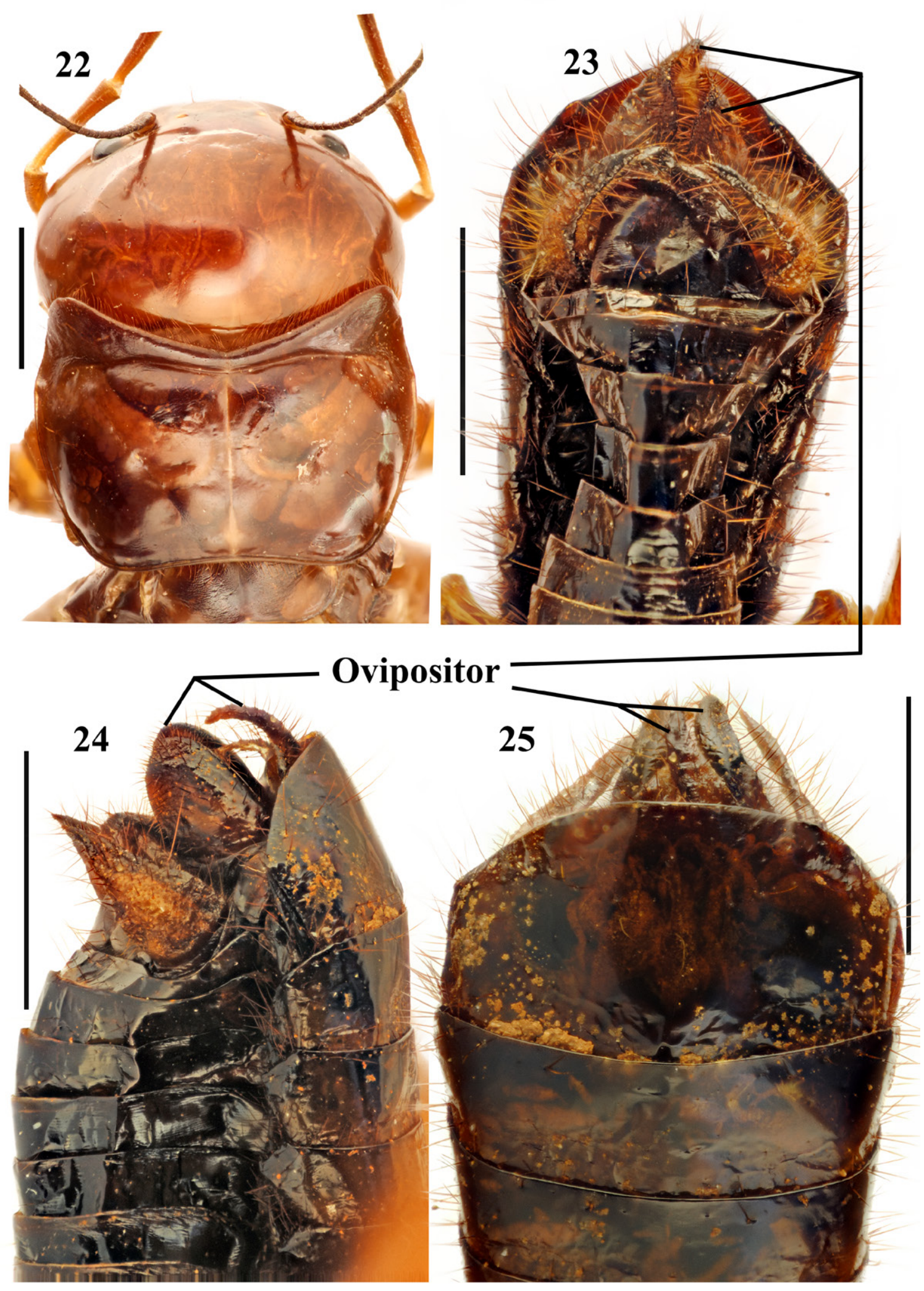

Figs 22-25. Oryctopterus varuna sp. nov. Paratype, $q$ (NBAIR). 22. Head and pronotum, dorsal view. 23-25. Apex of abdomen in preserved specimen. 23. Dorsal view. 24. Lateral view. 25. Ventral view. Scale bars $=5 \mathrm{~mm}$. 


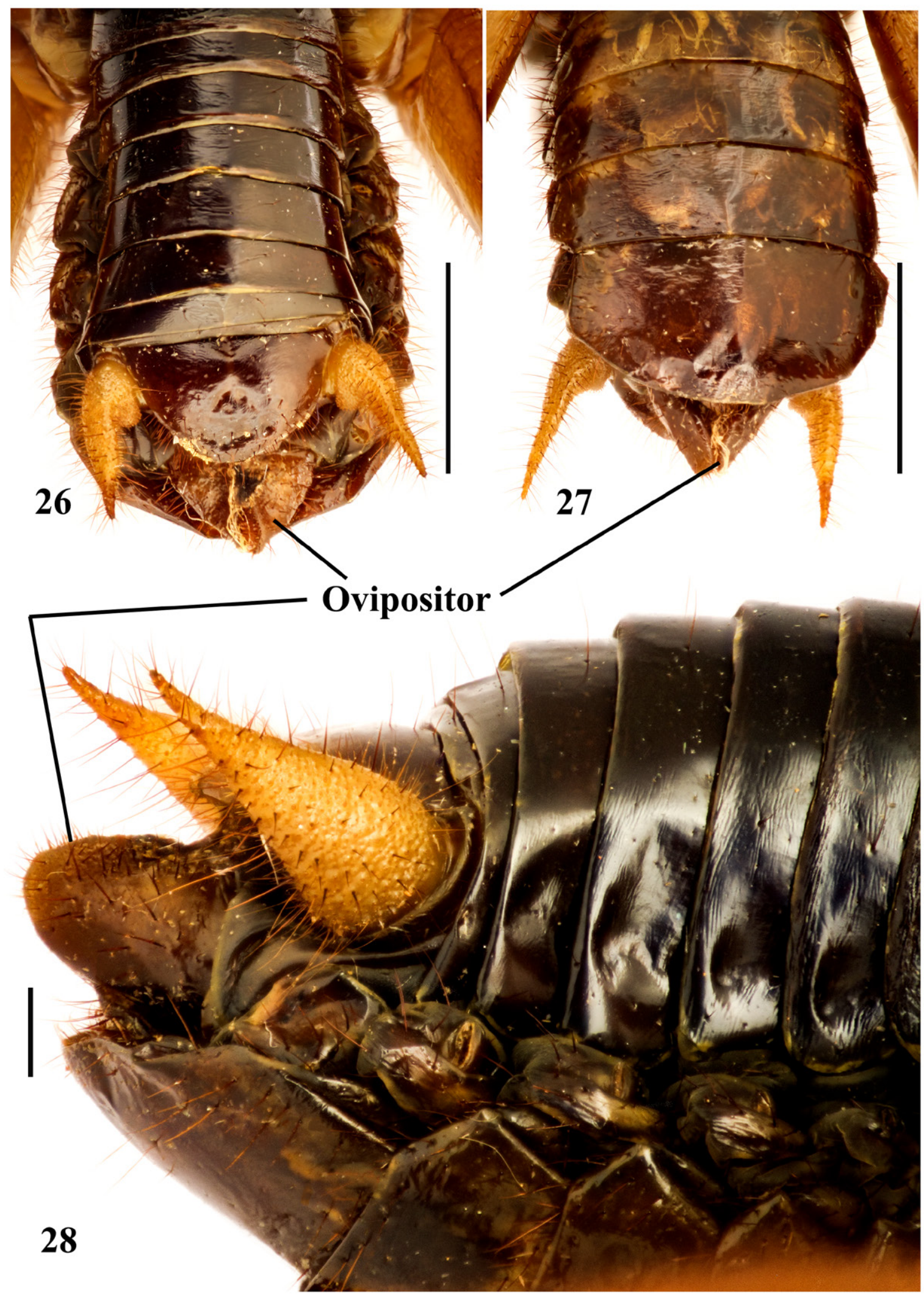

Figs 26-28. Oryctopterus varuna sp. nov. Apex of male abdomen in freshly killed specimen (NBAIR). 26. Dorsal view. 27. Ventral view. 28. Lateral view. Scale bars: $26-27=5 \mathrm{~mm} ; 28=1 \mathrm{~mm}$. 

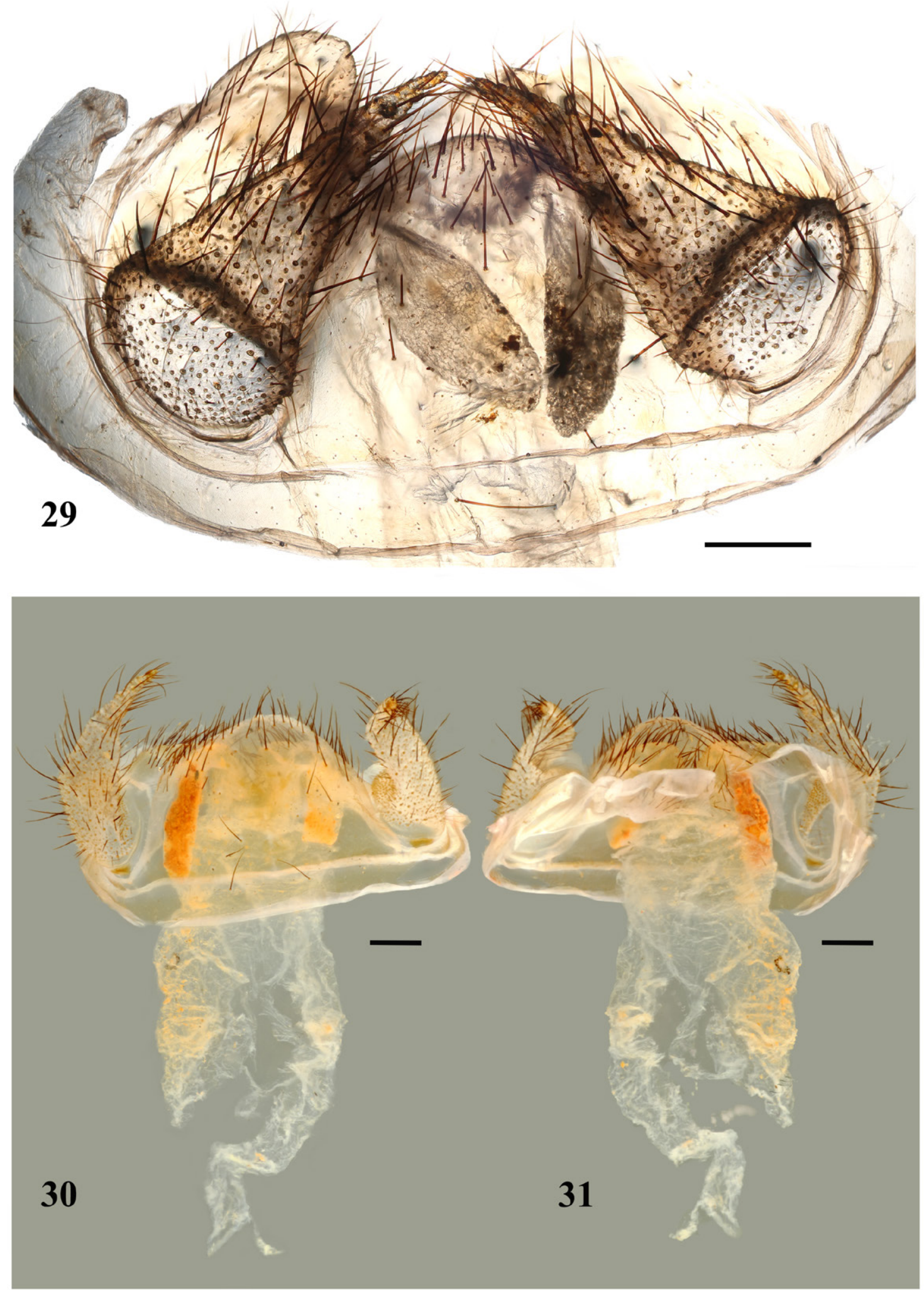

Figs 29-31. Oryctopterus varuna sp. nov. Paratype, $q$ (NBAIR). 29. Supragenital plate and cerci, dorsal view (macerated specimen, through transmitted light). 30. Supragenital plate, cerci and alimentary canal, dorsal view (macerated specimen). 31. Supragenital plate, cerci and alimentary canal, ventral view (macerated specimen). Scale bars $=1 \mathrm{~mm}$. 
acutely narrowed distally, oblique; prosternite distally with raised setose portion medially. Metathoracic basisternum with posterior margin emarginate medially.

Hind LEgs. Coxa depressed ventrally. Dorsolateral and dorsomesal margins of metatibia with a row of five small denticles, proximal one or two hardly noticeable.

Abdomen (Figs 23-28). Supragenital plate almost semicircular (Figs 23, 26, 29-31). Subgenital plate with arcuate posterior margin (Figs 25, 27).

Genitalia (Figs 32-36). Ovipositor with dorsal valve broader and slightly longer than ventral one. Base of ventral valve with two pairs of obliquely placed rod shaped sclerites, inner one shorter than outer. Vagina longer than dorsal valve, conical with lateral sides each bearing an elongate, rectangular, unsclerotized vaginal plate at middle. Spermathecal duct elongate, narrow tube with spindle shaped bulb near middle, entering vagina dorsally at middle. Median oviduct merged with ventral wall of vagina. Spermatheca spherical, with smooth integument. Spermathecal gland tubular, narrower and distinctly longer than spermathecal duct. Spermathecal gland with two spindle shaped bulbs near basal third and slightly elongate, spindle shaped bulb at apex (Fig. 36). Sternite VIII transverse with apical margin broadly rounded and weakly projected at middle, integument concentrated with elongate red-brown setae (Fig. 34).

Measurements $(\mathrm{mm})(\mathrm{n}=4)$. Body length: $26.02-37.64$, head width: 8.62-12.57, pronotal length: 5.13-7.29, pronotal width: 8.57-13.05, forefemur: 7.71-10.13, foretibia: 9.95-13.77, foretarsi: I. 4.426.05, II. 1.01-1.78, III. 0.86-1.49, IV. 0.67-1.01, midfemur: 6.63-9.23, midtibia: 7.44-11.24, midtarsi: I. 2.59-3.60, II. 0.82-1.34, III. 0.96-1.25, IV. 1.63-2.30, hindfemur: 10.23-14.20, hindtibia: 9.53-13.62, hindtarsi: I. 3.17-5.38, II. 1.20-1.68, III. 1.20-1.68, IV. 1.92-2.88. Proportionate length of forefemur: foretibia: foretarsi: midfemur: midtibia: midtarsi: hindfemur: hindtibia: hindtarsi as follows: 1.00: 1.16-1.36: 0.89-1.09: 0.70-0.91:0.94-1.11: 0.76-0.84: 1.27-1.40: 1.15-1.34: 0.97-1.05. Proportionate length of tarsomeres I-IV: foreleg - 1.00: 0.23-0.29: 0.19-0.25: 0.15-0.17; midleg - 1.00: 0.32-0.39: 0.29-0.37: 0.47-0.68; hindleg - 1.00: 0.27-0.45: 0.27-0.41: 0.43-0.65.

\section{Sexual dimorphism}

Male $(27.50-37.68 \mathrm{~mm})$ apparently subequal in length to the female $(26.02-37.64 \mathrm{~mm})$, with fully developed wings, female apterous and stouter. Claws of forelegs well developed in male, absent in female. Spines on metatibia well developed and sharp in male, much reduced or hardly discernible in the female.

\section{Remarks}

Oryctopterus varuna sp. nov. and Ot. lagenipes were geographically isolated multiple times in the Quarternary and most recently during the separation of Sri Lanka from south India, around 7500 years ago with the Holocene rises in sea level (Gunatilaka 2000). Poorly developed hind wings indicate that Ot. varuna sp. nov. could be flightless, despite being alate. Wing venation varies considerably, in the branching pattern, shape of veins and cross veins (Figs 10-12). Béthoux (2012) showed that in king crickets, raspy crickets and weta, wing venation vary greatly within species and several species delimited based on wing venation are synonyms. Ross (2012), who studied cockroaches, proved that forewings of a cockroach species vary considerably; even the left and right wings on the same specimen are slightly different. According to Ross (2012), since forewings in cockroaches are not used for active flight, the positions of the veins, which are important for the aerodynamics and flexing of the wings, vary greatly. The intraspecific variation in the wing venation in Oryctopterus, could be the outcome of a flightless, subterranean mode of life. 


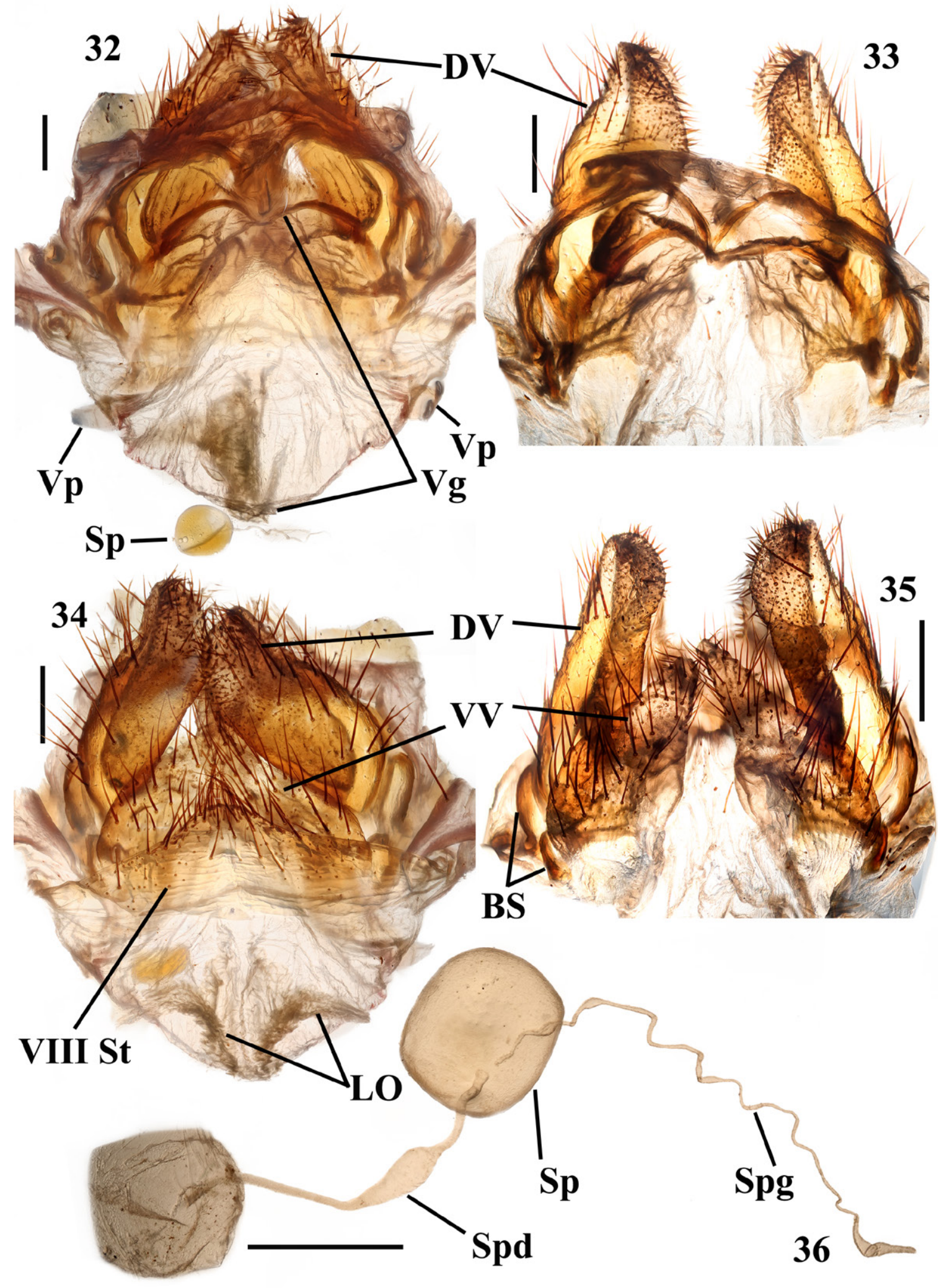

Figs 32-36. Oryctopterus varuna sp. nov., female genitalia. Paratype (NBAIR). 32. Dorsal view. 33. Dorsal view (valves separated). 34. Ventral view. 35. Ventral view (without sternite VIII). 36. Spermatheca Abbreviations: see Material and methods. Scale bars $=1 \mathrm{~mm}$. 

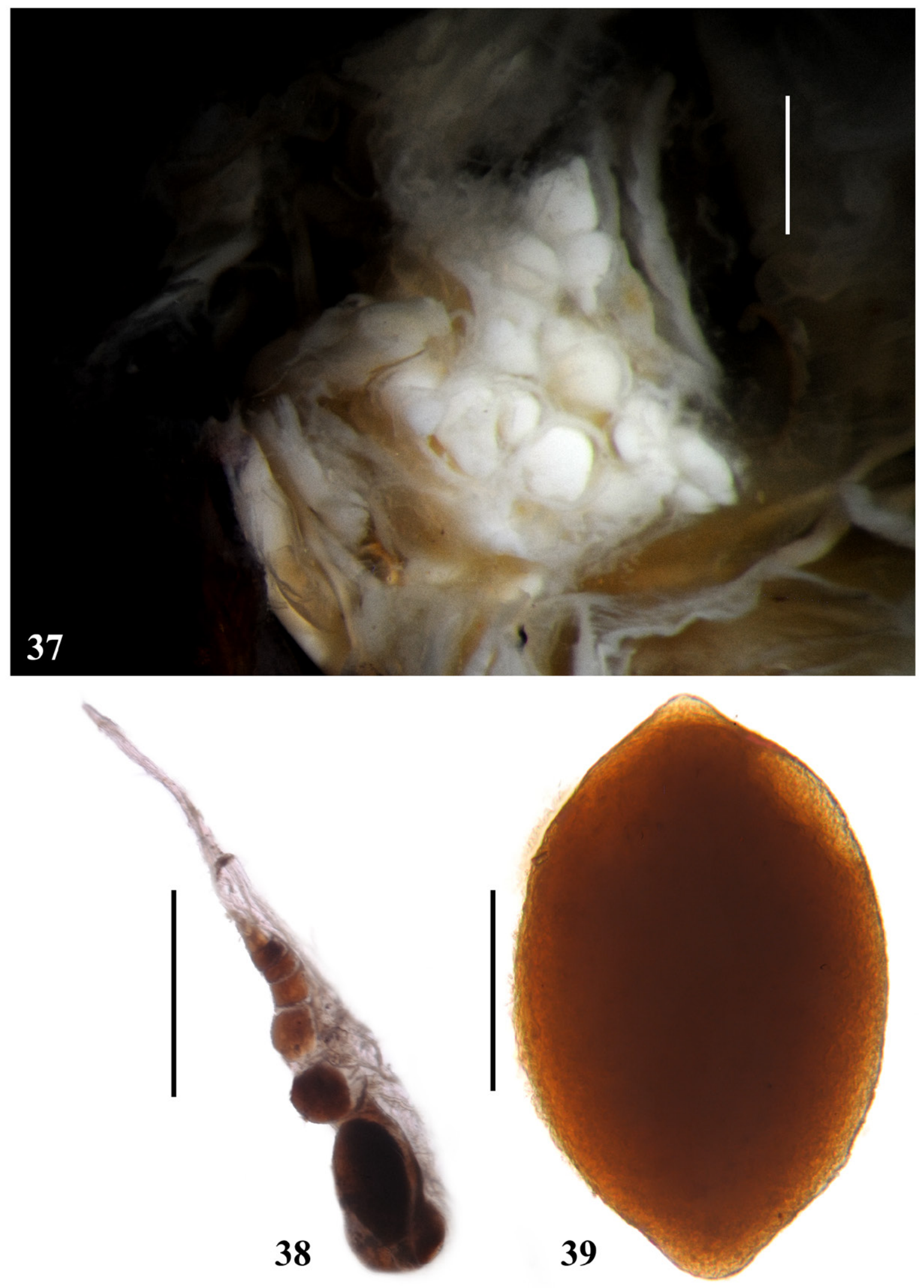

Figs 37-39. Ovary, ovarioles and egg of Oryctopterus varuna sp. nov. Paratype, ㅇ (NBAIR). 37. Ovary. 38. Ovariole. 39. Egg. Scale bars: $37-38=1 \mathrm{~mm} ; 39=0.1 \mathrm{~mm}$. 
Oryctopterus varuna sp. nov. is only known from the Vellayani campus of the Kerala Agricultural University ( $8^{\circ} 25^{\prime} 46.3^{\prime \prime} \mathrm{N}, 76^{\circ} 59^{\prime} 07.8^{\prime \prime} \mathrm{E}, 39 \mathrm{~m}$ elevation). Description of this new species underscores the importance of biodiversity conservation in periurban areas, as reckless development is taking its toll on all life forms in every imaginable habitat, throughout India and elsewhere.

\section{Notes on biology}

\section{Female reproductive system}

Ovaries were paired and each ovary (Fig. 37) consists of more than 10 panoistic ovarioles, each ovariole containing about six eggs (Fig. 38). A total of about 175-200 eggs were present inside the ovaries of an individual. Mature eggs are lemon-shaped (Fig. 39). Fully developed eggs in the ovary indicate that the dissected as well as the other examined specimens, which are morphologically identical, are probably all adults.

\section{Habitat}

Vellayani campus of the Kerala Agricultural University is the sole known habitat of the new species. The total area of the campus is about $2.52 \mathrm{~km}^{2}$. This is a highly populated residential area and the open lands are under cultivation with various agricultural crops. Chemical fertilizers and pesticides are used to raise the crops. The campus has a network of roads connecting academic and residential buildings and other facilities. The soil type is red loam and the average annual rainfall is $1577 \mathrm{~mm}$.

\section{Seasonality}

Most females were seen walking on the open campus roads during or after a downpour, both during day and night. One individual was caught around midday on 8 September 2019, when it was bright and sunny. Emergence of females of Ot. varuna sp. nov. coincides with the south-west monsoon rains during June to September. However, males are extremely rare and two individuals were collected following summer rains during the peak summer of March 2021.

Food habits as indicated by the gut contents (Figs 40-47)

Examination of the gut contents of three of the specimens revealed the presence of mandibles of mandibulate soldiers (Figs 40-41) and workers (Fig. 42) of the termite Odontotermes sp. (Blattaria, Termitidae); and the body parts, including head (Fig. 43), thorax (Figs 44-45), and abdomen of ants (probably Pheidole sp., Hymenoptera, Formicidae). Interestingly, a piece of the stem of a plant $(0.58 \mathrm{~mm} \times 0.43 \mathrm{~mm})($ Fig. 46) and sand particles (0.24-0.62 mm diameter) (Fig. 47) were also observed inside the gut.

\section{Behavior}

The new species is a 'heel-walker' (Fig. 49, Supp. file 3). They walk on the distal tip of tibiae with the foretarsi always held raised, while the mid- and hind tarsi are in close proximity to the ground, yet not touching it while walking. However, when not moving, all the tarsi may touch the ground. While walking, the long maxillary palpi are held forward and constantly touch the objects in the foreground in tandem. South African Jerusalem Crickets are known to hop and climb vegetation (Weissman \& Bazelet 2013) while some of the New World species exhibit drumming (abdomen striking against the substrate) (Weissman 2001a). However, no such behaviors were observed in O. varuna sp. nov. When a female was held above the ground level on a flat substrate, it rather tumbled down instead of hopping. It also failed to climb up sticks on which it was placed. A male was observed flapping wings and performing short jumps of about $0.3 \mathrm{~m}$.

\section{Defense}

Oryctopterus varuna sp. nov. displayed intricate defensive postures when intimidated. Confronted from the front, the cricket sprang into a pouncing posture, raised its forelegs and waved in mid-air, 


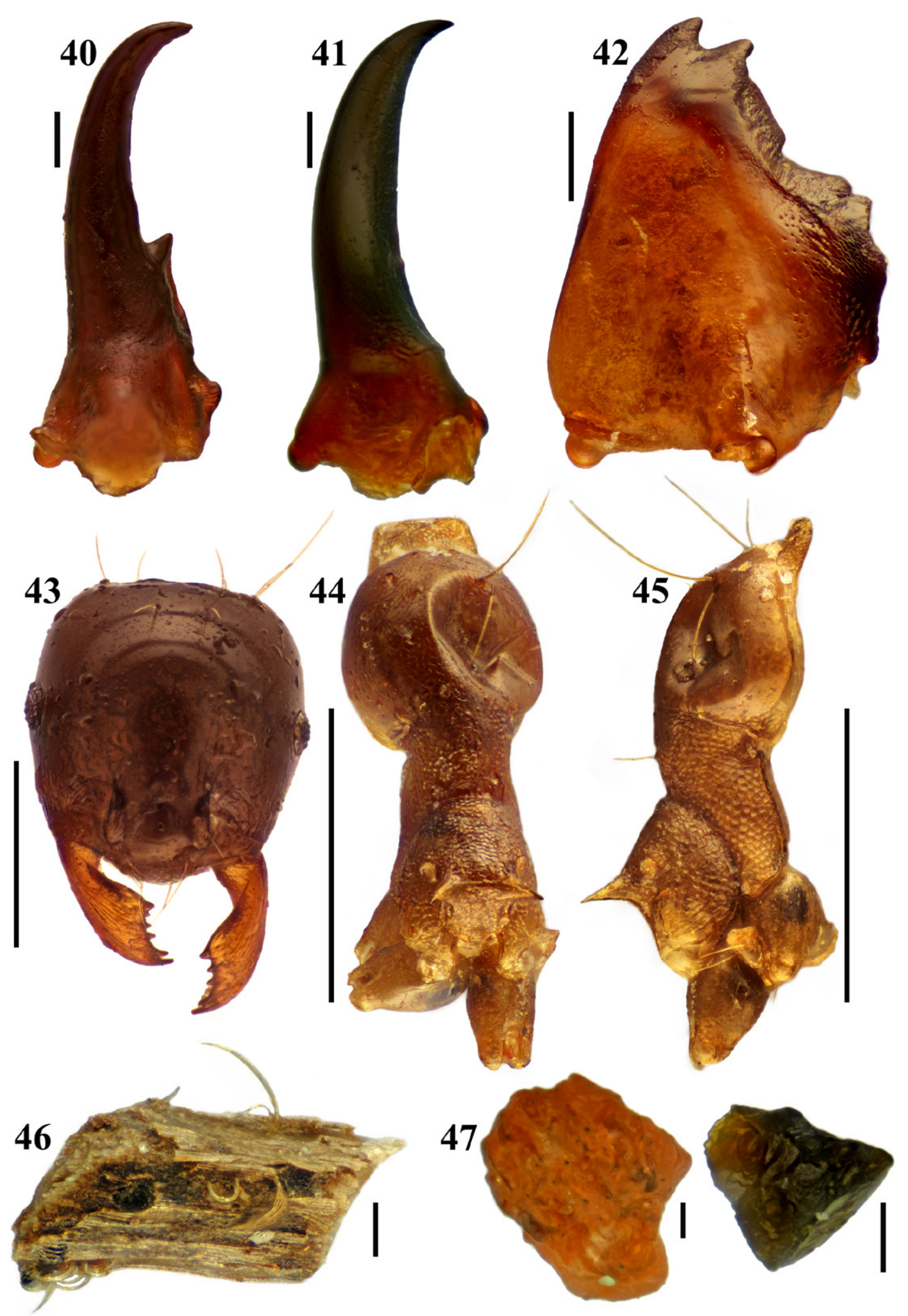

Figs 40-47. Gut contents of Oryctopterus varuna sp. nov. 40-41. Mandibles of Odontotermes sp. soldier. 42. Mandible of Odontotermes sp. worker. 43. Head of Pheidole sp. 44-45. Thorax of Pheidole sp. dorsal and lateral views. 46. Piece of stem. 47. Pebbles. Scale bars: $40-42,46-47=0.1 \mathrm{~mm} ; 43-45=0.5 \mathrm{~mm}$. 

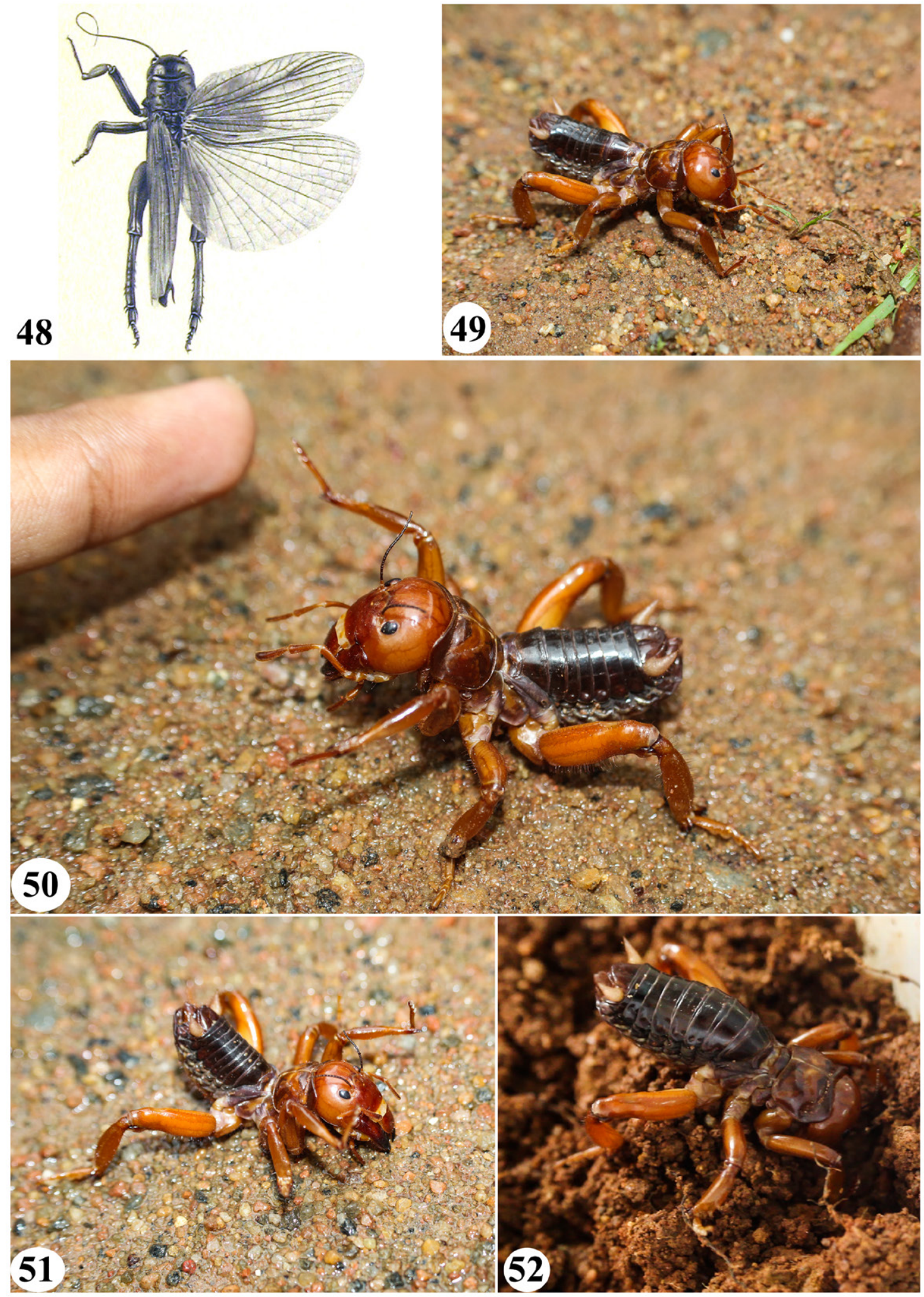

Figs 48-52. Oryctopterus species. 48. Oryctopterus lagenipes (Karny, 1935), allotype, $\partial$, from Colombo, Sri Lanka (Karny 1937: pl. 7 fig. 2; available from Orthoptera species file). 49-52. Oryctopterus varuna sp. nov. 49. Walking posture. 50. Defending a frontal attack. 51. Abdomen and fore-legs raised when poked on thorax. 52. Initiation of digging. Images not to scale. 
the mandibles opened widely, as if ready to bite (Fig. 50, Supp. file 1). When approached from the anterolateral side, it raised the front leg on that side to defend. However, when the animal was poked on the thorax, in addition to the forelegs, the abdomen also was raised, to startle the attacker (Fig. 51). When an individual is pinned down with the index finger firmly pressed on the thorax, the whole body was flexed and all legs were raised and started kicking to fend off the assailant. They inflicted painful bites when handled. Weissman (2001a) reported that New World Stenopelmatine, when confronted, frequently flip on their back, with mandibles agape, or can rear up.

\section{Burrowing}

Burrowing was observed by releasing an adult female into a $23.50 \mathrm{~cm}$ high, $21.50 \mathrm{~cm}$ wide polypropylene tub filled with loose soil up to $2 / 3$ the height of the tub. Mainly head and legs are used in burrowing. To begin with, the forelegs were firmly held against the ground to anchor the body, then the head was bent down, moving forward and backward to dig up the soil, with the mandibles acting like a shovel (Fig. 52, Supp. file 2). The dug-up soil was then pushed backwards and sideways with hindlegs and midlegs respectively. In the laboratory, it made a burrow that was vertical initially but turned oblique, then horizontal and nearly parallel to the surface. Observed behavior suggests that the Oryctopinae are subterranean, inhabiting underground burrows.

Oryctopterus yeshwanthi sp. nov.

urn:1sid:zoobank.org:act:82E702C9-26A7-485A-BC72-097B4B93D8B8

Figs $53-70$

\section{Diagnosis}

Oryctopterus yeshwanthi sp. nov. superficially resembles Ot. varuna sp. nov. However, Oryctopterus yeshwanthi sp. nov. can be easily recognized by the longer mandibles with five visible denticles (in female of Ot. varuna sp. nov., mandibles extend beyond labrum, but are shorter than in Ot. yeshwanthi sp. nov. and no denticles are externally visible); lateral margins of pronotum strongly curved in anterior third and nearly straight posteriorly (in Ot. varuna sp. nov., the lateral margin of pronotum is rather evenly curved), pronotum in Ot. yeshwanthi sp. nov. is posteriorly narrower than in Ot. varuna sp. nov. and the oblique sulcus originating from postero-lateral corners is well developed (pronotum is less strongly narrowed posteriorly in Ot. varuna sp. nov. and the oblique sulcus originating from posterolateral corners of pronotum is hardly discernible); and bean-shaped spermatheca with reticulated integument (spermatheca spherical with smooth integument in Ot. varuna sp. nov.). Moreover, the two species can also be separated based on the structure of the spermathecal duct, gland and sternite VIII. Spermathecal duct with cylindrical bulb post-medially (spermathecal duct with spindle shaped bulb near its middle in Ot. varuna sp. nov.); spermathecal gland shorter than spermathecal duct, with two bulged portions (spermathecal gland distinctly longer than spermathecal duct in Ot. varuna sp. nov.); apical margin of sternite VIII indistinctly emarginated medially with dorsal infolding (apical margin of sternite VIII broadly rounded and weakly projected at its middle in Ot. varuna sp. nov.). Supragenital plate and subgenital plate in the dry, preserved specimen were shrunk and deformed, hence maceration of specimens was required to ascertain the actual structure and shape.

Oryctopterus yeshwanthi sp. nov. resembles Ot. lagenipes in having dark stripes on head, which are similar to those in the latter. The sulci on pronotum are also more or less similar in both the species. However, Ot. yeshwanthi sp. nov. can be separated from Ot. lagenipes based on clypeus which is transverse (trapezoidal in Ot. lagenipes), longer mandibles (shorter in Ot. lagenipes), strongly curved lateral margins of pronotum in anterior third (evenly curved in Ot. lagenipes). 


\section{Etymology}

This species is named after H.M. Yeshwanth, University of Agricultural Sciences, who collected the single known specimen.

\section{Type material}

\section{Holotype}

INDIA • ; Kerala, Kallar; 12 Nov. 2014; H.M. Yeshwanth leg.; "HOLOTYPE; Oryctopterus yeshwanthi sp. nov.; des. Hiremath \& Prathapan, 2019"; UASB.

\section{Description}

\section{Female (Figs 53-69)}

Coloration. General color chestnut brown; abdominal tergites darker than head and thorax, abdominal sternites lighter than tergites; legs not distinctly lighter than thorax. Vertex and frons demarcated by M-shaped dark marking; a U-shaped dark stripe, originating from M-shaped mark, extends vertically over vertex; beneath $\mathrm{M}$-shaped mark, a pair of inverted, drop-shaped lighter areas present; a broader stripe originates from dorsomesal margin of eye, extending vertically over vertex. A third pair of dark stripes extend between subgenal suture and occiput on either side of head. Clypeus concolorus with vertex, except anterior margin lighter. Labrum slightly darker than vertex. Thoracic sternites apparently lighter than tergites.

HeAD (Fig. 55). Vertex strongly convex. Distance between eyes 1.38 times distance between antennal sockets. Frons moderately convex between antennal sockets, gradually turning flat, then depressed ventrally; minutely transversely wrinkled ventrally. Eyes with mesal margin concave near antennal socket, lateral margin strongly rounded. Clypeus a little shorter than labrum, rectangular, strongly transverse, nearly three times wider than long, with an indistinct vertical carina in middle, surface hardly depressed on either side of carina. Visible part of mandibles about two times longer than labrum, with five denticles visible.

Thorax. Pronotum (Fig. 56) 1.64 times wider than long, anteriorly 1.26 times wider than posteriorly. Lateral margin strongly curved near anterior third, then becomes nearly straight posterior to that; anterolateral margin convex, forming somewhat obtuse angle with anterior margin. Posterior margin concave medially. Pronotal anteapical transverse impression merged with anterolateral depressions on either side. Oblique sulcus originating from postero-lateral corner of pronotum well developed. Prosternite wider than long, converge posteriorly, posterior margin emarginate medially, with two pairs of ventral cervical sclerites; lateral cervical sclerites acutely narrowed distally, oblique; prosternite distally with setose, raised portion medially. Metathoracic basisternum with posterior margin emarginate medially.

HIND LEgs. Coxa depressed ventrally. Metatibia with dorsolateral margin with three small denticles, dorsomesal margin with a row of four small denticles.

АвDOMEN (Figs 57-60). Supragenital plate wider than long, semicircular (Figs 61-62). Subgenital plate transverse, with posterior margin straight in middle (Figs 60, 63).

Female genitalia (Figs 64-69). Ovipositor with dorsal valve broader and slightly longer than ventral. Base of ventral valve with two pairs of obliquely placed thick sclerites; inner one short, oblong; outer one longer. Vagina longer than dorsal valve in length, semicircular with lateral sides each bearing an elongate, unsclerotized vaginal plate at middle. Spermathecal duct elongate, narrower in proximal half, then distinctly widened beyond middle up to distal third quarter, entering vagina dorsally, at middle. Median oviduct merged with ventral wall of vagina. Spermatheca nearly bean-shaped, surface with 


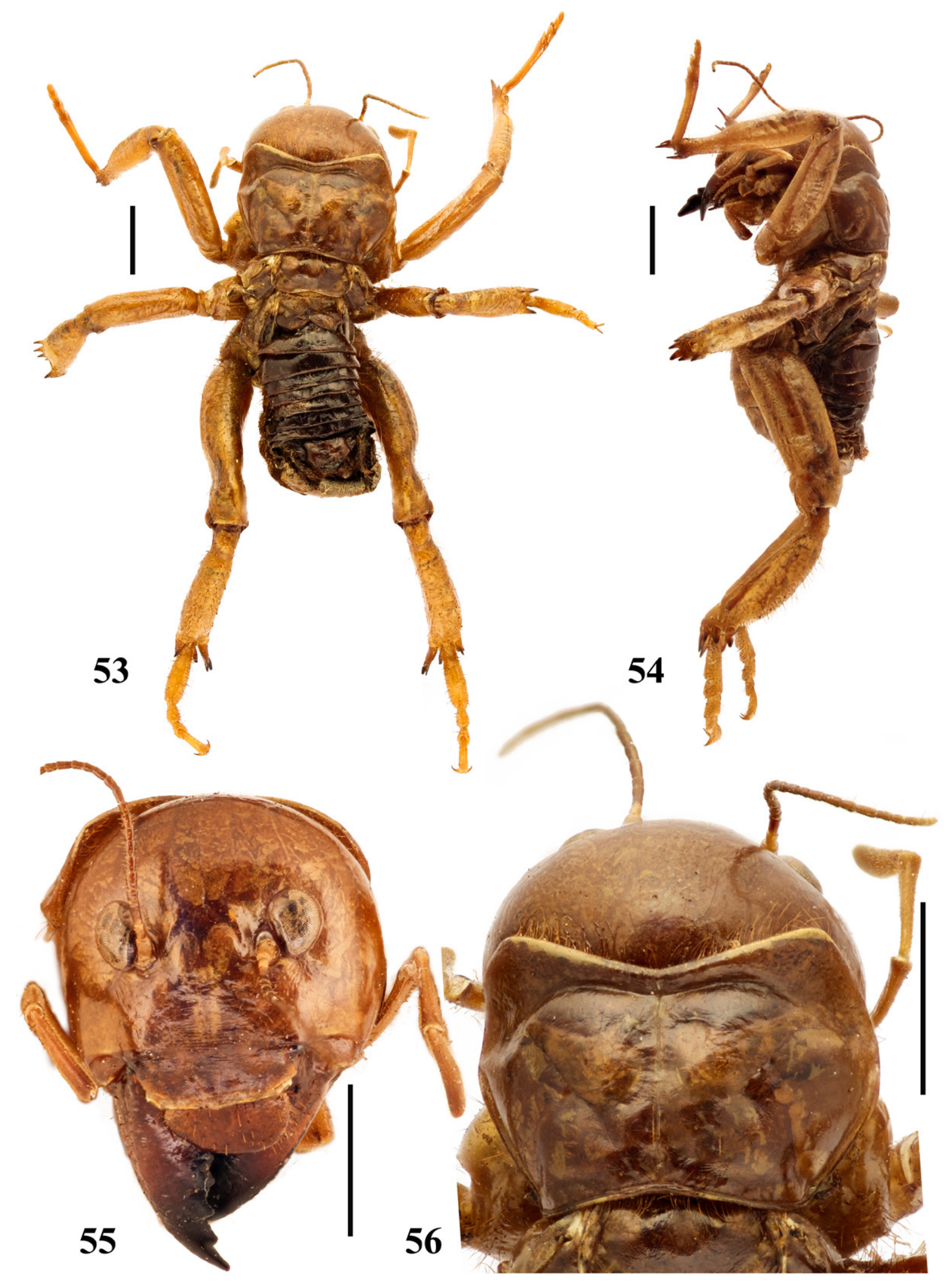

Figs 53-56. Oryctopterus yeshwanthi sp. nov. Holotype, $q$ (UASB). 53. Dorsal habitus. 54. Lateral habitus. 55. Head, frontal view. 56. Head and pronotum in dorsal view. Scale bars $=5 \mathrm{~mm}$. 

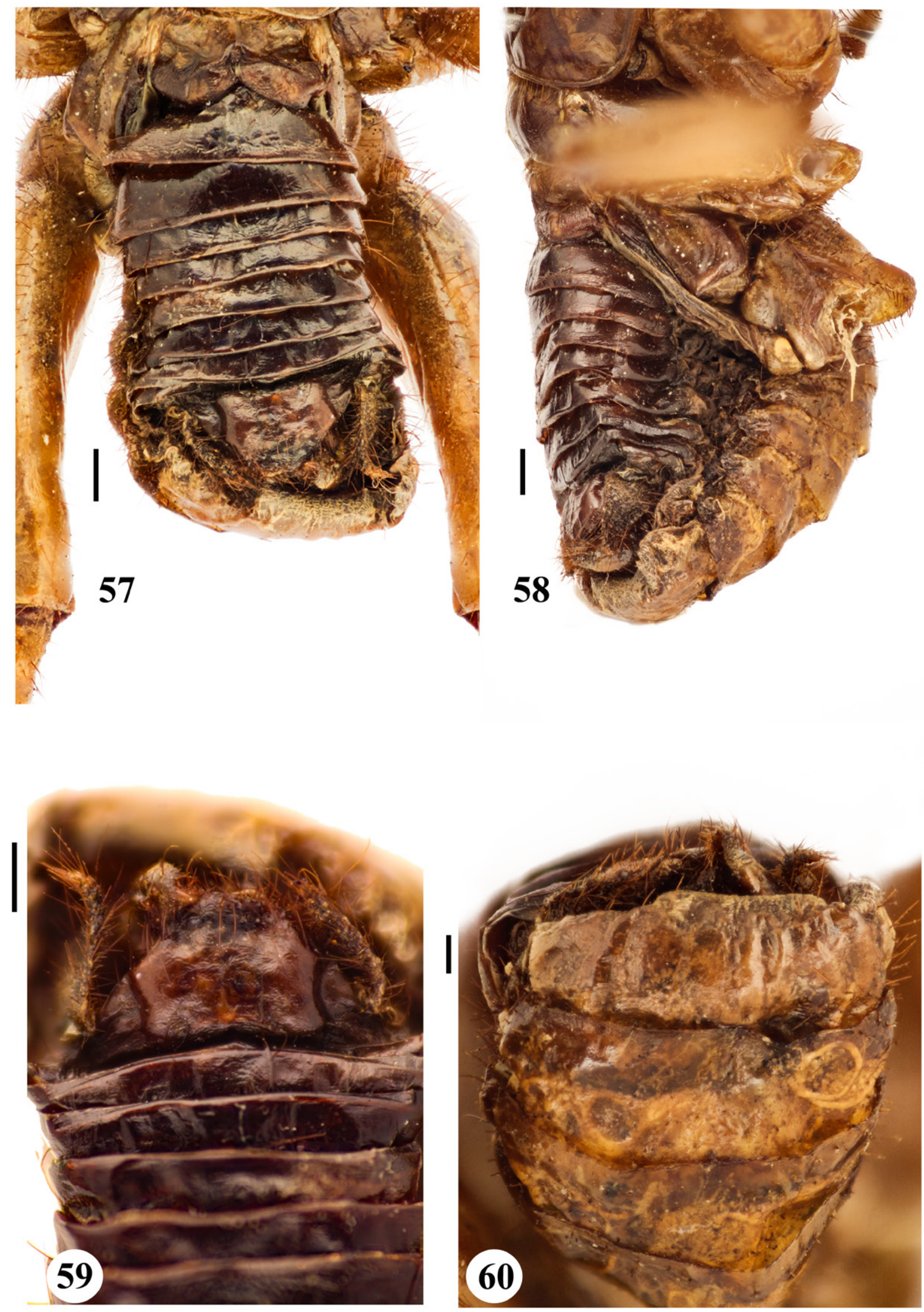

Figs 57-60. Oryctopterus yeshwanthi sp. nov. Holotype, + (UASB). 57. Abdomen, dorsal view. 58. Abdomen, lateral view. 59. Supragenital plate. 60. Subgenital plate. Scale bars $=1 \mathrm{~mm}$. 

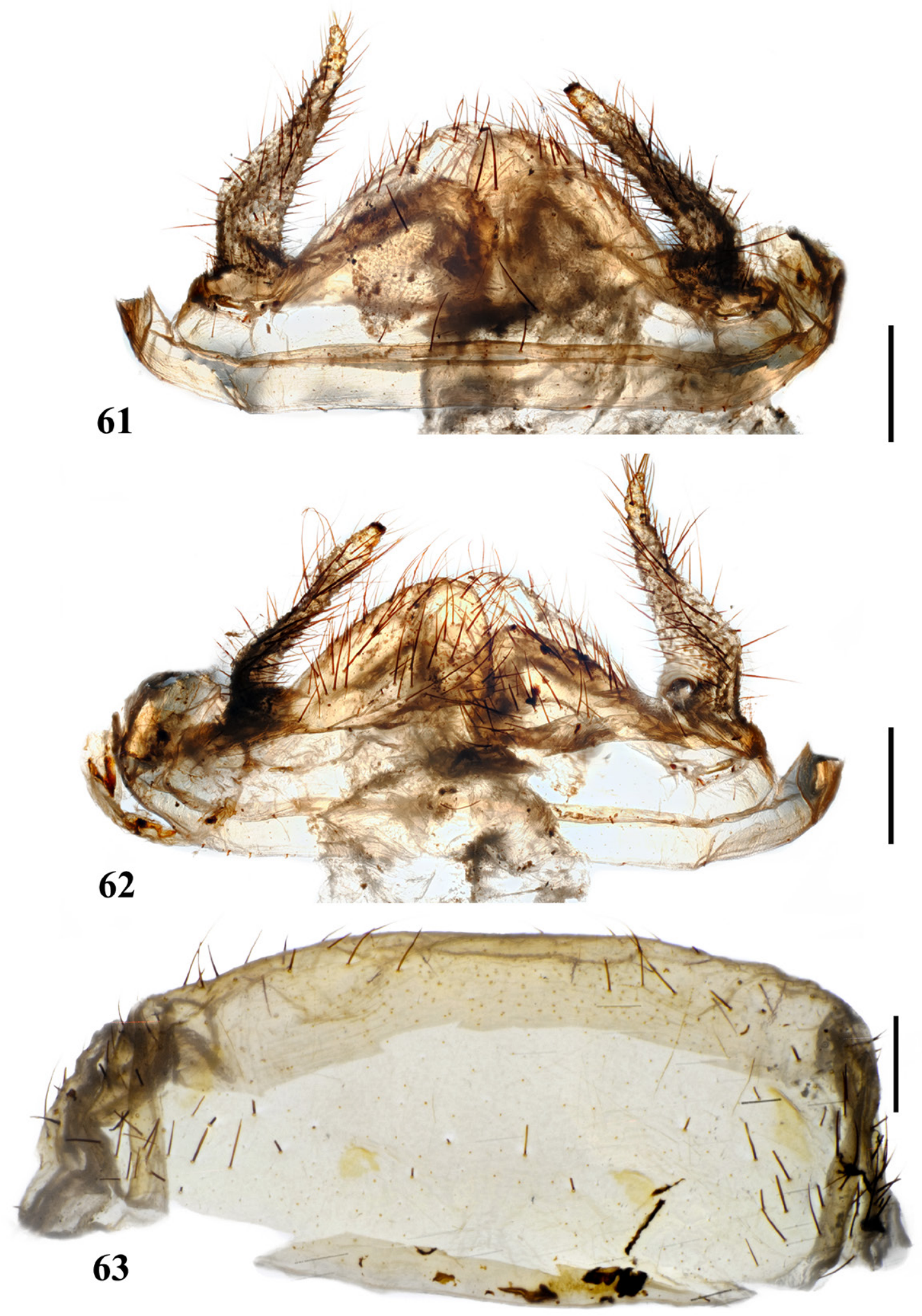

Figs 61-63. Oryctopterus yeshwanthi sp. nov. Female genitalia. Holotype (UASB). 61. Supragenital plate, dorsal view (macerated specimen). 62. Supragenital plate, ventral view (macerated specimen). 63. Subgenital plate, dorsal view (macerated specimen). Scale bars $=1 \mathrm{~mm}$. 

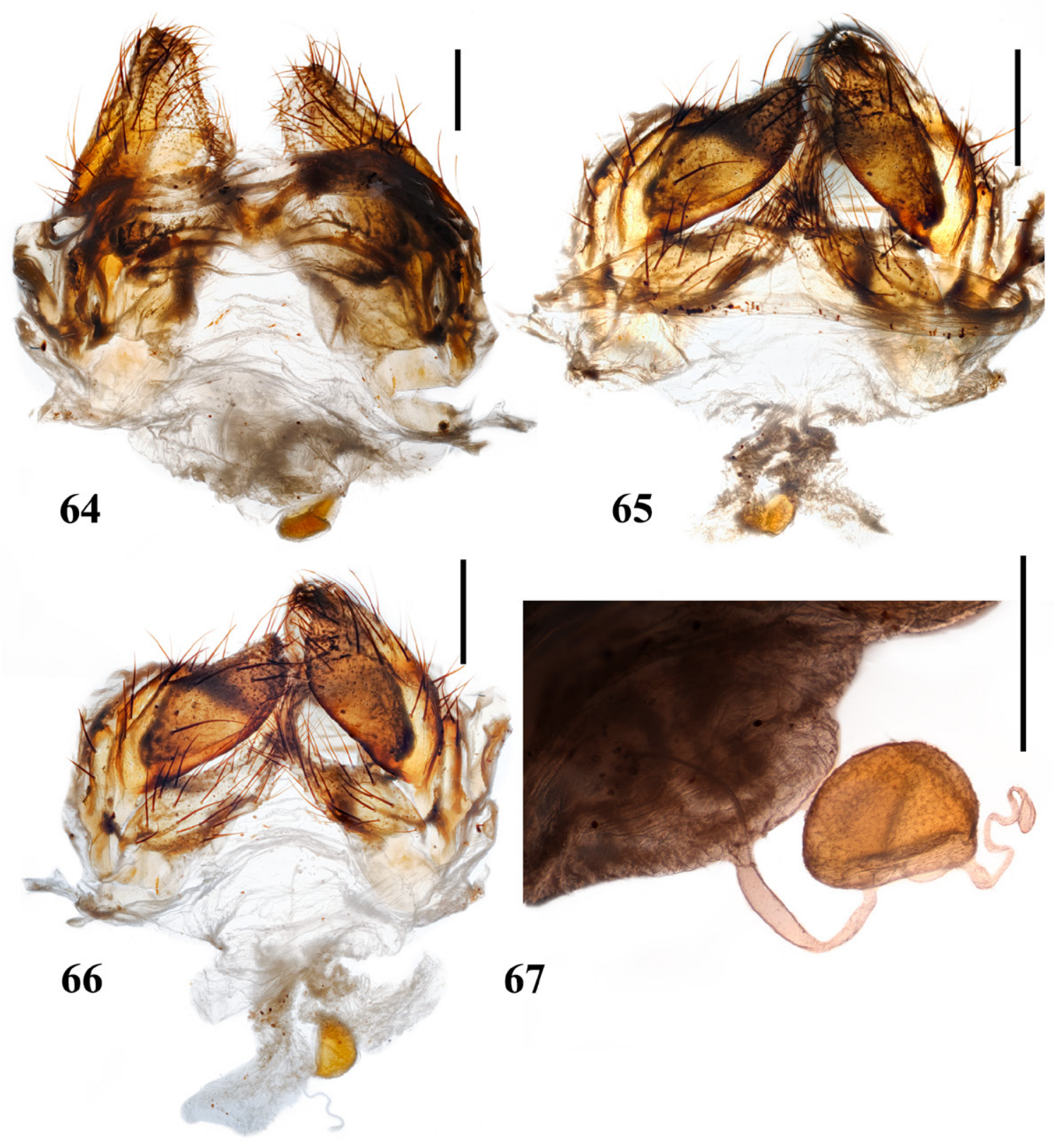

67
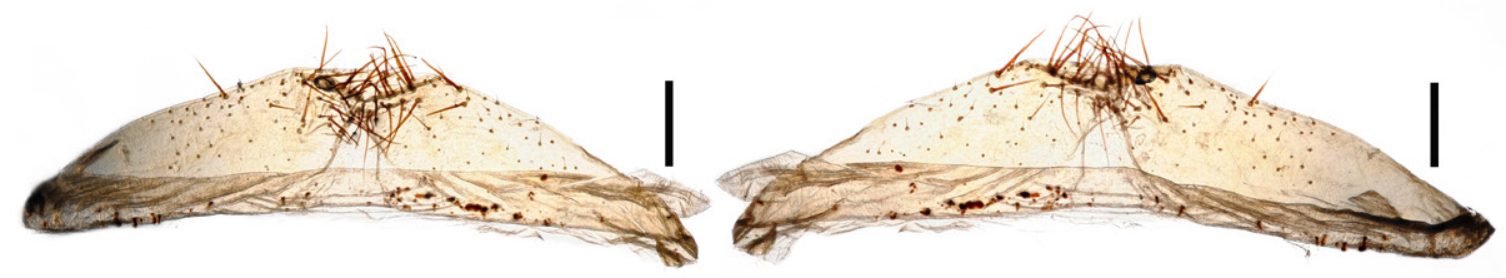

68

69

Figs 64-69. Oryctopterus yeshwanthi sp. nov., female genitalia. Holotype (UASB). 64. Dorsal view. 65. Ventral view with VIII sternite intact. 66. Ventral view without VIII sternite. 67. Spermatheca. 68. VIII Sternite, dorsal view. 69. VIII Sternite, ventral view. Scale bars $=1 \mathrm{~mm}$. 
depressions, integument reticulated (Fig. 67). Spermathecal gland elongate, shorter than spermathecal duct, bulged near proximal third and distal end. Sternite VIII (Figs 68-69) transverse, in ventral view with apical margin indistinctly emarginate medially, with a dorsal infolding bearing several elongate setae; in dorsal view distal margin emarginate medially.

Measurements $(\mathrm{mm})(\mathrm{n}=1)$. Body length: 25.15 , head width: 9.87 , pronotal length: 6.20 , pronotal width: 10.18, forefemur: 8.64 , foretibia: 11.00, foretarsi: I. 5.04, II. 1.44, III. 1.25, IV. 0.82, midfemur: 7.21, midtibia: 9.08, midtarsi: I. 3.74, II. 1.39, III. 1.20, IV. 1.92, hindfemur: 12.58, hindtibia: 11.83, hindtarsi: I. 4.13, II. 1.44, III. 1.25, IV. 2.50. Proportionate length of fore-femur: foretibia: foretarsi: midfemur: midtibia: midtarsi: hindfemur: hindtibia: hindtarsi as follows: 1.00: 1.27: 0.99: 0.83: 1.05: 0.95: 1.46: 1.37: 1.08. Proportionate length of tarsomeres I-IV: foreleg - 1.00: 0.29: 0.25: 0.16; midleg1.00: 0.37: 0.32: 0.51; hindleg- 1.00: 0.35: 0.30: 0.61 .

\section{Male \\ Unknown.}

\section{Notes on biology}

\section{Habitat}

Kallar, the type locality of the new species, is on the lower reaches of the Agasthyamalai Biosphere Reserve at the southern end of the Western Ghats biodiversity hotspot. Most of Kallar still retains the forest cover and is slated to form part of the newly proposed Ponmudi Wildlife Sanctuary.

\section{Behavior}

The single specimen was picked up on a bright sunny day (H.M. Yeshwanth pers. com., 18 September 2019).

\section{Discussion}

Both the south Indian species of Oryctopterus appear to be highly restricted in distribution. Mobility and dispersal of Oryctopinae may be restricted as they are mostly wingless and are unable to jump or run. Vandergast et al. (2007, 2009), who studied an endemic Stenopelmatus Burmeister, 1838 Jerusalem cricket in California, showed that genetic connectivity among populations has been disrupted by urban development and flightless arthropods are especially sensitive to habitat fragmentation. One of the new species described here, Ot. varuna sp. nov., is known only from a single campus and the distribution of Ot. yeshwanthi sp. nov. is probably limited also. Hence, they should be accorded special conservation status until their ranges are better determined.

We believe that all females studied by us are adults, as two of them carried mature eggs and the rest of them were morphologically identical. However, the ovipositor valves were unsclerotized in all the specimens. Structure of the female genitalia, including the shape of spermatheca, which is sparingly used in the taxonomy of Stenopelmatidae, offers reliable characters in species delimitation. Discovery of Ot. varuna sp. nov. and Ot. yeshwanthi sp. nov. extends the distributional range of Oryctopinae in south India to Kerala. The other three south Indian species are restricted to Tamil Nadu and Pondicherry (Fig. 70).

This is the first description of the food habits and behavior of Oryctopinae. Examination of the gut contents in two of the field-collected specimens indicates a predatory mode of life. In captivity, they did not feed on oatmeal, potatoes or biscuits. Oatmeal trails in their habitat did not attract any individual. However, in captivity they fed on termites, ants, nymphs of grasshoppers, and larvae and pupae of the black soldier fly Hermetia illucens (Linnaeus, 1758) (Diptera: Stratiomyidae). They may ingest pieces of wood and sand, possibly to enhance grinding of the food in the gizzard, as 'gastroliths', in some birds (Wings \& Sander 2007), or as mineral supplements. 


\section{Acknowledgements}

We are indebted to Dr David Weissman, California Academy of Sciences, San Francisco, for guidance and support throughout the study. He also critically reviewed previous versions of the manuscript. Y.Y. Ruan provided a copy of Griffini (1914). Dr R. Swaminathan, Maharana Prathap University of Agriculture \& Technology, Udaipur critically reviewed the manuscript. C.M. Kalleswaraswamy, University of Agricultural \& Horticultural Sciences, Shivamogga, identified Odontotermes sp. and Manoj Vembayam, Travancore Natural History Society, identified Pheidole sp. Critical review by an anonymous reviewer greatly improved the manuscript. We are greatly indebted to Mr Prasanth S., College of Agriculture, Vellayani, who ran a successful social media campaign to collect the elusive males of Ot. varuna sp. nov. We also thank Mr Kumar A. and Mr Pradeep D. of the Instructional Farm, College of Agriculture, Vellayani for relentlessly searching for the males and finally collecting them.

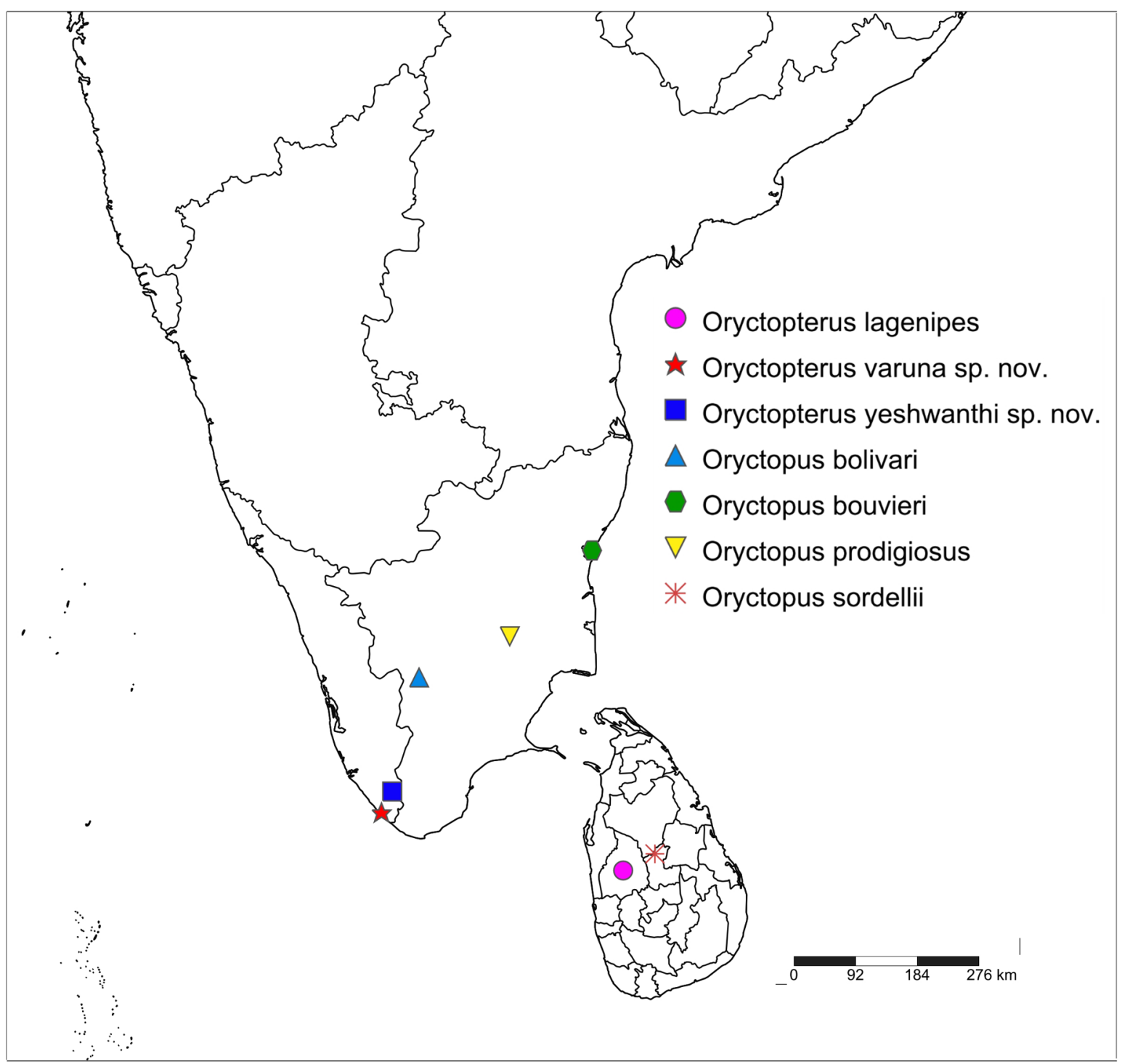

Fig. 70. Distribution of Oryctopinae Kevan, 1986 species. 


\section{References}

Béthoux O. 2012. King crickets, raspy crickets and weta, their wings, their fossil relatives. Journal of Orthoptera Research 21 (2): 179-225. https://doi.org/10.1665/034.021.0206

Cigliano M.M., Braun H., Eades D.C. \& Otte D. 2019. Orthoptera Species File. Version 5.0/5.0. Available from http://Orthoptera.SpeciesFile.org [accessed 9 Sep. 2019].

Gorochov A.V. 2001. The higher classification, phylogeny and evolution of the superfamily Stenopelmatoidea. In: Field L.H. (ed.) The Biology of Wetas, King Crickets and their Allies: 3-34. CABI Publishing, Wallingford.

Griffini A. 1914. Studi sopra alcuni Stenopelmatidi dell'Indian Museum di Calcutta. Atti della Società italiana di scienze naturali e del Museo civico di storia naturale di Milano 53: 46-72.

Gunatilaka A. 2000. Sea-levels as historical time-markers in prehistoric studies. Journal of the Royal Asiatic Society of Sri Lanka 45: 19-34.

Johns P.M. 1997. The Gondwanaland weta: family Anostostomatidae (formerly in Stenopelmatidae, Henicidae or Mimnermidae): nomenclatural problems, world checklist, new genera and species. Journal of Orthoptera Research 6: 125-138. https://doi.org/10.2307/3503546

Karny H.H. 1937. Orthoptera. Fam. Gryllacrididae, subfamiliae omnes. In: Wytsman P. (ed.) Genera Insectorum 206: 1-317. Available from https://www.biodiversitylibrary.org/item/223806

O'Brien B. \& Field L.H. 2001. Morphology and anatomy of New Zealand Wetas. In: Field L.H. (ed.) The Biology of Wetas, King Crickets and their Allies: 127-162. CABI Publishing, Wallingford.

Ross A.J. 2012. Testing decreasing variabililty of cockroach forewings through time using four recent species: Blattella germanica, Polyphaga aegyptiaca, Shelfordella lateralis and Blaberus craniifer, with implications for the study of fossil cockroach forewings. Insect Science 19: 129-142.

https://doi.org/10.1111/j.1744-7917.2011.01465.x

Shishodia M.S., Chandra K. \& Gupta S.K. 2010. An annotated checklist of Orthoptera (Insecta) from India. Records of the Zoological Survey of India, Miscellaneous Publication, Occasional Paper 314: 1-366. Available from http://faunaofindia.nic.in/PDFVolumes/occpapers/314/index.pdf [accessed 9 Sep. 2019].

Vandergast A.G., Bohonak A.J., Weissman D.B. \& Fisher R.N. 2007. Understanding the genetic effects of recent habitat fragmentation in the context of evolutionary history: phylogeography and landscape genetics of a southern California endemic Jerusalem cricket (Orthoptera: Stenopelmatidae: Stenopelmatus). Molecular Ecology 16: 977-992.

https://doi.org/10.1111/j.1365-294X.2006.03216.x

Vandergast A.G., Lewallen E.A., Deas J., Bohonak A.J., Weissman D.B. \& Fisher, R.N. 2009. Loss of genetic connectivity and diversity in urban microreserves in a southern California endemic Jerusalem cricket (Orthoptera: Stenopelmatidae: Stenopelmatus n. sp. "santa monica"). Journal of Insect Conservation 13: 329-345. https://doi.org/10.1007/s10841-008-9176-z

Weissman D.B. 2001a. North and Central American Jerusalem crickets (Orthoptera: Stenopelmatidae): taxonomy, distribution, life cycle, ecology and related biology of the American species. In: Field L.H. (ed.) The Biology of Wetas, King Crickets and their Allies: 57-72. CABI Publishing, Wallingford.

Weissman D.B. 2001b. Communication and reproductive behaviour in North American Jerusalem crickets (Stenopelmatus) (Orthoptera: Stenopelmatidae). In: Field L.H. (ed.) The Biology of Wetas, King Crickets and their Allies: 351-373. CABI Publishing, Wallingford. 
Weissman D.B. \& Bazelet C.S. 2013. Notes on southern Africa Jerusalem crickets (Orthoptera: Stenopelmatidae: Sia). Zootaxa 3616 (1): 49-60. https://doi.org/10.11646/zootaxa.3616.1.4

Weissman D.B., Judge K.A., Williams S.C., Whitman D.W. \& Lee V.F. 2008. Small-male mating advantage in a species of Jerusalem crickets (Orthoptera: Stenopelmatinae: Stenopelmatus). Journal of Orthoptera Research 17: 321-332. https://doi.org/10.1665/1082-6467-17.2.321

Wings O. \& Sander P.M. 2007. No gastric mill in sauropod dinosaurs: new evidence from analysis of gastrolith mass and function in ostriches. Proceedings of the Royal Society B 274: 635-640.

https://doi.org/10.1098/rspb.2006.3763

Yamasako J. 2015. A method to observe membranous structures of female genitalia in the inflated condition (Coleoptera: Cerambycidae). The Coleopterists Bulletin 69 (4): 799-805.

https://doi.org/10.1649/0010-065X-69.4.799

Manuscript received: 14 October 2019

Manuscript accepted: 6 August 2020

Published on: 7 May 2021

Topic editor: Nesrine Akkari

Desk editor: Pepe Fernández

Printed versions of all papers are also deposited in the libraries of the institutes that are members of the EJT consortium: Muséum national d'histoire naturelle, Paris, France; Meise Botanic Garden, Belgium; Royal Museum for Central Africa, Tervuren, Belgium; Royal Belgian Institute of Natural Sciences, Brussels, Belgium; Natural History Museum of Denmark, Copenhagen, Denmark; Naturalis Biodiversity Center, Leiden, the Netherlands; Museo Nacional de Ciencias Naturales-CSIC, Madrid, Spain; Real Jardín Botánico de Madrid CSIC, Spain; Zoological Research Museum Alexander Koenig, Bonn, Germany; National Museum, Prague, Czech Republic.

\section{Supplementary files}

Supp. file 1: Defence behaviour of Oryctopterus varuna sp. nov. https://doi.org/10.5852/ejt.2021.748.1349.4177

Supp. file 2: Digging behaviour of Oryctopterus varuna sp. nov. https://doi.org/10.5852/ejt.2021.748.1349.4179

Supp. file 3: Walking behaviour of Oryctopterus varuna sp. nov. https://doi.org/10.5852/ejt.2021.748.1349.4181 